Florida International University FIU Digital Commons

$12-1984$

\title{
A study to analyze the degree of hurricane preparedness in selected Miami Beach hotels
}

Gina Brink

Florida International University

DOI: $10.25148 /$ etd.FI14051840

Follow this and additional works at: https://digitalcommons.fiu.edu/etd

Part of the Hospitality Administration and Management Commons

\section{Recommended Citation}

Brink, Gina, "A study to analyze the degree of hurricane preparedness in selected Miami Beach hotels" (1984). FIU Electronic Theses and Dissertations. 1895.

https://digitalcommons.fiu.edu/etd/1895

This work is brought to you for free and open access by the University Graduate School at FIU Digital Commons. It has been accepted for inclusion in FIU Electronic Theses and Dissertations by an authorized administrator of FIU Digital Commons. For more information, please contact dcc@fiu.edu. 


\title{
A STUDy TO ANALYZE THE DEGREE OF HURRICANE PREPAREDNESS \\ IN SELECTED MIAMI BEACH HOTELS
}

by

Gina Brink

\begin{abstract}
A thesis submitted in partial fulfillment of the requirements for the degree of MASTER OF SCIENCE
\end{abstract}

in

HOSPITALITY MANAGEMENT

at

FLORIDA INTERNATIONAL UNIVERSITY 
To Professors Joe Gregg and P. Darby:

This hospitality project is being referred to you for judgment upon its substantial merit.

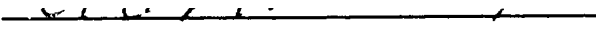

Dean Anthony G. Marshall

School of Hospitality

The hospitality project of Gina Brink is approved.

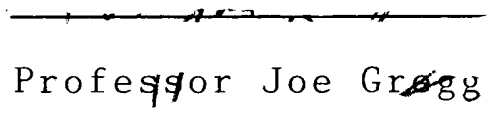

Professor P. Darby

Date of examination: December 1984 


\section{PREFACE}

This research paper is presented to the faculty of Florida International University in partial fulfillment of the requirements leading to a Master of Science Degree in Hospitality Management at this institution. Through the course of the paper the researcher will discuss the effects a hurricane could have on the hospitality industry on Miami Beach. The vulnerability of this city and its hotels will be analyzed. The paper will then shift its focus to the present, when a survey will be conducted to identify to what degree the hotels on Miami Beach are prepared for the emergency of a hurricane. The results will then be discussed in light of the problem.

The researcher would like to take this opportunity to acknowledge the help and support of the following persons during the course of the project:

Prof. N. Ringstrom

Prof. Joe Gregg, Advisor

Prof. P. Darby

Mr. R. McMul1en, Office of Emergency Management

A11 General Managers and other management personnel of the selected hotels in this study

Without the support of these and other friends too numerous to be mentioned, this project could not have been attempted. 
THE QUALIFICATIONS OF THE RESEARCHER

Gina Brink was born in 1959 in Holland, Europe, where she finished High School.

In 1977, she studied French and English for one year at a 'Finishing School' in Switzerland.

In 1978, she immigrated to the island of St.Maarten, Netherlands Antilles, where she was an administrative assistant to her father, helping him with all the paperwork necessary to build and develop his new resort hotel.

In 1979 , Gina worked as an Activities Hostess at the Mullet Bay Beach Resort on St.Maarten.

From January 1980 until December 1981, Gina attended Miami Dade Community College/New World Center, where she received an Associate in Arts degree in Business Administration. She continued her education at the University of Florida in Gainesville, receiving a Bachelor of Science from the College of Business Administration .

To satisfy her interests in the hospitality field, Gina Brink came to back to Miami to do post graduate work at Florida International University, with the objective of obtaining a Masters of Science degree in Hotel and Restaurant Management. As part of her studies at Florida International University she worked as an intern at the Front Desk of the Holiday Inn at Ca1der Race Course, North Miami. 
FOR THOSE WHO HAVEN'T FELT THE FORCE OF A HURRICANE *

It was pleasant - a breezy summer Sunday evening. As the hurricane approached the beautiful saucer-deep bay, longtime residents sat on their patios and sipped tall drinks. The last hurricane was on 1 y a dim 22-year old memory. The storms broke their once-every-six-year average of hitting the coast long ago. When they did hit, it never amounted to more than a splash of water blown up to the property line or porch steps. Evacuate in response to civil defense sirens and radio warnings? Why bother? They were having too much fun!

But by morning the bridge was out. They were stuck. Record 200 mile per hour plus winds shredded their homes splinter by splinter, as they cowered in upper floor back bedrooms, clinging to mattresses.

Those alive tried to concentrate on shutterless flashbacks of their lives as they waited in terror for the end. Then a mighty storm surge plowed inland, its giant wind-driven waves over 20 feet high, strewing devastation, and finishing what the wind had started.

This could happen to you!

\footnotetext{
* "Hurricane." (Miami: Metropolitan Dade County Office of Emergency Management, 1984$)$.
} 
TABLE OF CONTENTS

Chapter

Page

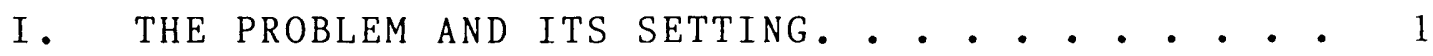

A. Statement of the Problem. . . . . . . 1

B. Hypothesis. . . . . . . . . . . 1

C. Delimitation. . . . . . . . . . 1

D. Assumptions . • . . . . . . . . . . . 1

E. Definitions . . . . . . . . . . 2

F. Importance of the Study . . . . . . 3

II. THE REVIEW OF THE RELATED Literature . . • . . . 6

A. Florida and Hurricanes. . . . . . 6

B. Origin of the Word "Hurricane". . . . 7

C. Hurricane Season. . . . . . . . 8

D. Frequency of Hurricanes in Dade County. 8

E. Intensity of a Hurricane. . . . . . . 12

F. Response Rate to a Hurricane Warning. • 14

G. Hurricane Probabilities . . . . . . 18

H. The 1926 Hurricane: an Example. •. . . 19

I. Storm Surge . . . . . . . . . 21

J. The "Hurricane" Building Code . . . • 24

K. Evacuation. . . . . . . . . 26

L. Preparation for a Hurricane . . . . 30 SUMMARY AND CONCLUSIONS. • • • • • • • • • 35

III. GENERAL PROCEDURES . • • • • • • • • • • • 37

A. The Data... . . . . . . . . 37

1. Primary Data....... . . 37

2. Secondary Data. . . . . . . 37

B. The Criteria Governing the Admissibility of the Data. . . . . . . . . 38

C. The Research Methodology. . . . . . . 38 
Table of Contents (continued)

Chapter

Page

III .

D. The Questionnaires. . . . . . 39

E. The Subjects. . . . . . . . . 40

F. The Treatment of the Problem. •. 41

1. Data Needed........ . 41

2. Location of the Data. . . . 42

3. The means of Obtaining the Data 42

4. Treatment and Interpretation

of the Data........ . 42

IV. THE RESUlTS. . . . . . . . . . . 44

A. Discussion of the Responses . . . 44

B. The hypothesis. . . . . . 57

C. Summary of Results. . . . . . 59

V. SUMMARY, CONCLUSIONS, AND RECOMMENDATIONS. 62

A. Summary ........... 62

B. Conclusions . . . . . . . 63

C. Recommendations ....... 64

APPENDIX A Hurricane Refuge Capacities. . 66 APPENDIX B Dade County Traffic-Evacuation Zonal Data...... 67

APPENDIX $C$ Dade County Assumed Evacuee

Percentages by Destination

APPENDIX D Sample Cover Letter. . . . 69

APPENDIX E Sample Questionnaire •. . . 70

APPENDIX F Sample Table of Contents of a Hurricane Preparedness Plan. • 72

APPENDIX G Example of a Simple Hurricane Preparedness Plan. • • . 73 
Table of Contents (continued)

Page

APPENDIX $H$ Three Examples of an Extensive Hurricane Preparedness Plan. . . 74

APPENDIX I American Red Cross - Recommendations for Hurricane Planning . . 92

APPENDIX J Evacuation Notice by the Governor. 95

SELECTED BIBLIOGRAPHY • • • • • • • • • • 96

A. Books, magazines and newspapers... . 96

B. Bulletins and unpublished papers. • . 97 


\section{LIST OF TABLES}

Table

Page

2.1 Past Hurricanes Causing Destruction in Florida 
LIST OF FIGURES

Figure

Page

2.1 Hurricane Tracks Since 1900

10

2.2

Dade County Evacuation Zones

22 


\section{APPENDICIES}

Appendix

Page

A

Hurricane Refuge Capacities

B

Dade County Traffic-Evacuation Zonal Data

C Dade County Assumed Evacuee Percentages by Destination Type

D Sample Cover Lette

E Sample Questionnaire

F Sample Table of Contents for a Hurricane Preparedness Plan

G Example of a Simple Hurricane Preparedness Plan

H Three Examples of an Extensive Hurricane Preparedness Plan

I American Red Cross: Recommendations for Hurricane Planning 
CHAPTER I

THE PROBLEM AND ITS SETTING 


\section{CHAPTER T}

THE PROBLEM AND ITS SETTING

A. Statement of the problem

The purpose of this study is to analyze the degree of hurricane preparedness in selected Miami Beach hotels.

$$
\text { B. Hypothesis }
$$

The hypothesis is that most hotels on Miami Beach are not well enough prepared for a hurricane. Hotel managers know the dangers of a hurricane but they do not spend enough time to prepare an emergency plan.

\section{Delimitation}

The study will be limited to selected sea-front hotels on Miami Beach with one hundred and fifty rooms or more.

\section{Assumptions}

The first assumption is that hurricanes will continue to be with us at least at their present frequency.

The second assumption is that people will continue to make use of the hotels on Miami Beach and that their demand for safer hotels will continue. 
Hurricane: A hurricane is a severe tropical cyclone with sustained wind velocities of seventy-four miles per hour or higher. A hurricane is often accompanied on the beachfront by a storm surge. 1

Hurricane Watch: Hurricane conditions pose a possible threat to a certain coastal area. ${ }^{2}$

Hurricane Warning: Hurricane conditions are expected in a specified coastal area within 24 hours. 3

Landfal1: The period of time in which hurricane winds, rain and storm tide present a danger to the general population as the storm approaches land and passes through the area. 4

Storm surge: A great dome of seawater 12 or more feet high and 40 to 50 miles across, which sweeps ashore at the point where the eye of the storm makes landfall, creating a series of destructive waves. 5

NOAA: Nationa1 Oceanic and Atmospheric Administration.

${ }^{1}$ Gilbert F. White and Eugene Haas, Assessment of Research on Natural Hazards (Cambridge, Massachusetts:The MIT Press, 1975), p. 242 .

2 "Surviva1 in a hurricane, "Pamphlet, National Hurricane Center, 1984.

3 Ibid.

${ }^{4}$ Hurricane Procedure Plan, Section I Miami: Metropo1itan Dade County Office of Emergency Management, 1984).

${ }^{5}$ Hurricane (Miami: Metropolitan Dade County Office of

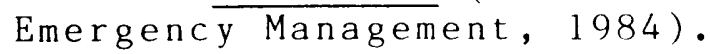


Miami Beach: All tourist facilities in the corporate limits from Government Cut on the South to 87 th Terrace on the North.6

Guest: A guest is a person who presents him-or herself to an innkeeper or his agent or servant; who requests accomodations and pays for these; and who gives the innkeeper an opportunity to receive or reject him or her. 7

Guest safety: Guest safety includes those measures required to promote a state of well-being for the guest, to protect his or her life and property and to minimize exposure of the guest to natural or man-made disasters or crime. 8

\section{F. Importance of the study}

It is necessary and important to know what can happen to thousands of people in coastal areas when one day they will be hit by hurricane wind and storm surge. Between 1960 and 1970 , the number of people living and vacationing on the coast soared more than 40 percent. 9 During the last 50 years, a great number of hotels has been built on Miami Beach, which makes this area more vulnerable than it ever was before.

${ }^{6}$ Dade County Tourism Facts (Miami: Metro-Dade Department of Tourism, 1983).

7 Walter J.Buzby and David Paine, Hotel and Motel Security Management (Los Angeles, California: Security World Publishing Co., Inc., 1976): p, 48 .

8 Ibid., p. 6 .

${ }^{9}$ Ben Funk, "Hurricane!. "National Geographic, Sept. 1980 , p. 373 . 
Insuring the safety of its guests and employees under a11 circumstances is a very important part of a hotel's security and safety program. It should by all means be a preventive program - the prevention of those hazards that can hurt, injure or destroy 1 ives or property. All hotels should be extremely concerned with the safety of their guests and with the hotel's property. While the hotel's responsibility to a guest may differ in degree, the innkeeper must avoid any injuries or unpleasantness as far as possible. When a hurricane threatens, management's responsibilities are probably even greater because lots of 1 ives are at stake.

Safety and security go hand in hand. Security plans are needed to maintain guest safety. Security is a living thing and does not remain fixed. Conditions change continuously: personnel changes, new hazards arise, new security measures are developed both in Dade County and within the hotel. Concepts and physical equipment change. A hotel's security system should keep pace with the changes that are taking place, especially these days when people are expecting and demanding safer hotels and rooms. People are also less afraid to file law suits against a hotel that did not provide "reasonable care" for its guests. These are some of the reasons why hotels should accept a proper standard of care and develop a hurricane preparedness plan. More important, however, is that these standards and plans are known and enforced by management. 
The thought behind this thesis is that most hotels know what should be done in terms of emergency planning but that they for some reason - be it laziness, lack of control or lack of money - do not develop a written plan or do not put it into action.

Miami is again becoming one of the most frequent $1 y$ visited cities and all travelers in general are more safetyand security-conscious than ever. Therefore it is important to know if the hotels on our beaches do in fact care enough about their guest's safety, especially in the event of a hurricane. If they don't, Miami Beach might experience a true disaster and may never be able again to revive its image in the field of hospitality and tourism. 
CHAPTER II

THE REVIEW OF THE RELATED LITERATURE 


\section{CHAPTER I I}

THE REVIEW OF THE RELATED LITERATURE

\section{A. Florida and Hurricanes}

Florida, jutting like a thumb into the sea between the subtropical Atlantic and the Gulf of Mexico, is the most exposed of all states. Hurricanes can approach from the Atlantic to the east, the Caribbean to the south, and the Gulf of Mexico to the west. Since it also extends farther southward than any other state, Florida experiences hurricanes which on the average are more intense. Because of their frequency and severity they are a most important factor in the Florida economy. 10

Hurricanes have struck the state from every quarter

". causing more than 2,500 deaths and $\$ 1.5$ billion in damage during this century." 11

Richard A. Frank, Administrator of the NOAA gave the following answer when asked what areas are most vulnerable to devastation when a hurricane hits:

". Florida, Texas, . - are very vulnerable states. During the $1970^{\prime} \mathrm{s}$, hurricanes have focused on the Gulf rather than the Atlantic. Specific areas that we worry about are Galveston, Texas, the Florida Keys and Miami.12

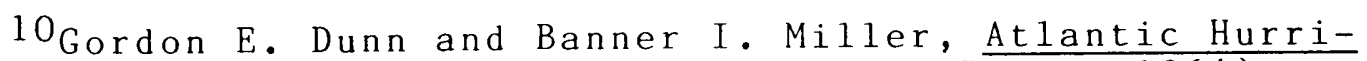
canes (Louisiana: Louisiana State University Press, 1964), p. 8.

11 Emergency Measures (Federal Emergency Management Agenс y, 1984$)$.

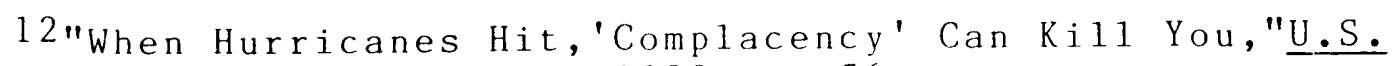
News and World Report, 18 Aug. 1980, p. 56. 
Bezold and Olson in their article about Florida's

future state that

- . statistical1y, Florida can expect to be hit each century by 21 hurricanes with winds over 125 miles per hour. 13

They further say that the Miami area has an $80 \%$ probability of being hit by hurricane-force winds during the 1980's.

The hotel line-up along Miami Beach is particularly vulnerable.

\section{B. Origin of the word 'hurricane'}

More than 13,000 people have been killed since 1900 in the United States alone by the dreaded hurricanes that rage across the Atlantic or spring from the Caribbean. The term 'hurricane' comes from the Spanish 'huracan', which in turn is thought to have originated from words in use among some of the Caribbean Indian tribes. Some of the translations for the word 'hurricane are 'evil spirit', 'storm god', 'big wind', and 'monster of the sea'. These words very well reflect an age-old terror. 14

Because of its considerable size and great intensity, a hurricane is said to be the most dangerous and destructive of al1 storms. In total damage, hurricanes have exceeded any other natural catastrophe.

13 Clement Bezold and Robert L. Olson, "The Future of Florida,"Futurist, Oct. 1983, p. 15 .

14 Funk, National Geographic, p. 361 . 
C. Hurricane Season

An old mariner's rhyme expresses the hurricane season as follows:

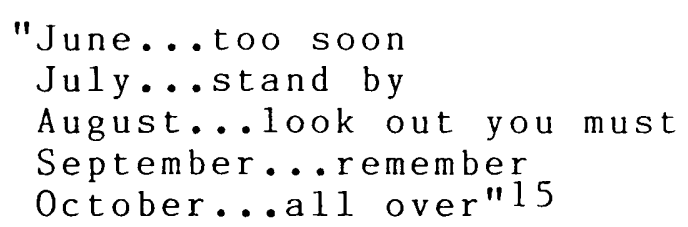

The official hurricane season is from June to November. Most hurricanes occur in August and September. However, there have been hurricanes as early as March and as late as December. Between June 1 and November 30 there will be an average of eight to ten tropical storms. Five or six will intensify into hurricanes. The average life of a hurricane is about nine days. August storms normally 1 ive the longest, with an average life span of twelve days.

For Dade County, the months of September and October are historically the most vulnerable. One third of all storms occur in September. 16

D. Frequency of hurricanes in Dade County

Southeast Florida, as shown in the Table on the next page, has been affected by a total of thirty-one hurricanes from 1900 to 1983. Fourteen of those have made landfall in

${ }^{15}$ Leonard G. Pardue, September, Remember... Weatherwatch (Miami, Florida, 1982), p. 1 .

16 Hurricane Procedure Plan, Section I 
Dade County. As can be seen the months of September and October have the highest incidence of hurricane landfall in the county.17

NUMBER OF HURRICANES SINCE 1900

BY COUNTY BY MONTH

MONTH

$\underline{\text { DADE }} \underline{\text { MONROE }}$ BROWARD PALM BEACH

June

$\mathrm{Ju} 1 \mathrm{y}$

August

September

October

November

December/May

TOTAL

$\begin{array}{lr}0 & 0 \\ 0 & 0 \\ 1 & 1 \\ 5 & 8 \\ 7 & 9 \\ 1 & 1 \\ 0 & 0 \\ 4 & 19\end{array}$

0

0

1

2

4

0

$\underline{0}$

\begin{tabular}{lr}
1 & 1 \\
1 & 1 \\
3 & 3 \\
6 & 14 \\
2 & 10 \\
0 & 2 \\
0 & 0 \\
\hline
\end{tabular}

14

19

13

Dunn and Miller in their book Atlantic Hurricanes confirm these statistics:

- In any September there is a 92 percent chance that there will be at least one tropical storm somewhere in the Atlantic and a 42 percent chance there will be three or more storms. 18

Figure 2.1 on the following page gives an overview of the hurricane tracks passing over South Florida since the beginning of this century

Table 2.1 shows all hurricanes that have caused destruction in Florida since the year 1919.

17 Ibid.

${ }^{18}$ Dunn and Miller, Atlantic Hurricanes, p. 52. 
FIGURE 2.1

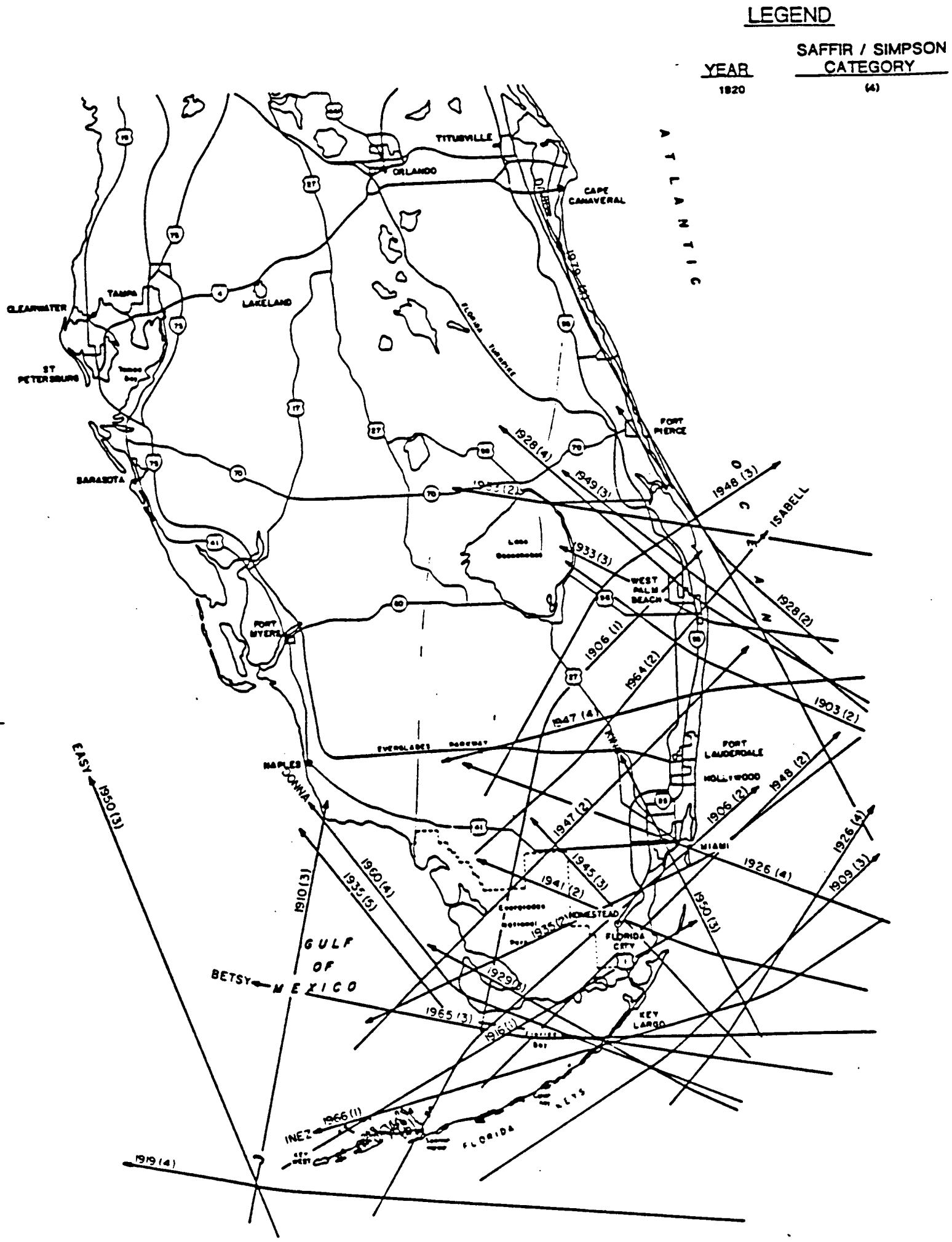

HURRICANE TRACKS SINCE 1900 
TABLE 2.1

PAST HURRICANES CAUSING DESTRUCTION IN FLORIDA*

\begin{tabular}{|c|c|c|c|}
\hline Name and date & $\begin{array}{l}\text { mph } \\
\text { Winds }\end{array}$ & Deaths & Damage and other facts \\
\hline (No name), Sept.1919 & $\mathrm{n} / \mathrm{a}$ & 287 & $\begin{array}{l}\text { Extreme; more than } 500 \\
\text { casualties at sea }\end{array}$ \\
\hline (No name), Sept. 1926 & 138 & 243 & Severe storm in Miami \\
\hline (No name), Sept. 1928 & 200 & 1,836 & $\begin{array}{l}\text { Severe flooding; most } \\
\text { people drowned }\end{array}$ \\
\hline (No name), Sept.1935 & 180 & 408 & Flooding \\
\hline (No name), Sept. 1945 & 150 & 4 & $\begin{array}{l}\text { Very heavy damage in } \\
\text { Dade County. Evacuation } \\
\text { of exposed locations } \\
\text { prevented heavy loss } \\
\text { of life }\end{array}$ \\
\hline (No name), Sept. 1947 & 120 & 51 & $\begin{array}{l}\text { Wind and water damage } \\
\text { heavy on FLorida east } \\
\text { coast }\end{array}$ \\
\hline King, Oct.1950 & 150 & 4 & Worst storm since 1926 \\
\hline Donna, Sept.1960 & 160 & 50 & $\begin{array}{l}\text { Record amount of damage } \\
\text { in Miami }\end{array}$ \\
\hline Cleo, Sept.1964 & 180 & 50 & $\begin{array}{l}\text { First hurricane in to } \\
\text { directly hit Miami } \\
\text { since hurricane King }\end{array}$ \\
\hline Betsy, Sept.1965 & $\mathrm{n} / \mathrm{a}$ & 75 & $\begin{array}{l}\text { Most damage caused by } \\
\text { flooding }\end{array}$ \\
\hline Agnes, June 1972 & $\mathrm{n} / \mathrm{a}$ & 122 & $\begin{array}{l}\text { Costliest natural dis- } \\
\text { aster in U.S. history }\end{array}$ \\
\hline E1oise, Sept. 1975 & $\mathrm{n} / \mathrm{a}$ & 4 & $\begin{array}{l}\text { Major storm surge and } \\
\text { wind damage to struc- } \\
\text { tures along beach strip }\end{array}$ \\
\hline David, Aug. 1979 & 150 & 12 & $\begin{array}{l}\text { Tornadoes; not much } \\
\text { damage }\end{array}$ \\
\hline Frederic, Sept.1979 & 135 & 5 & $\begin{array}{l}\text { Wind and storm surge } \\
\text { damage }\end{array}$ \\
\hline
\end{tabular}

* Adapted from "Hurricane Preparedness, "The Miami Herald, 19 July 1984, Sec. HA, p. 3. 
E. Intensity of a hurricane

The intensity of a hurricane or the potential for wind and storm surge damage can be divided into five categories. The Saffir/Simpson Scale gives a continuing assessment of the severity of a hurricane. Scale numbers are made available to the public within 72 hours of storm landfall and they are revised with each new observation. The following Table is an overview of the five categories of storms on the Saffir/Simpson Scale. 19

SAFFIR/SIMPSON SCALE

\begin{tabular}{|c|c|c|c|}
\hline CATEGORY & WINDS (MPH) & STORM TIDE(FT) & DAMAGE \\
\hline 1 & $74-95$ & $4-5$ & Minimal \\
\hline 2 & $96-110$ & $6-8$ & Moderate \\
\hline 3 & $111-130$ & $9-12$ & Extensive \\
\hline 4 & $131-155$ & $13-18$ & Extreme \\
\hline 5 & $155+$ & $18+$ & Catastrophic \\
\hline
\end{tabular}

Studies by the National Hurricane Center have shown that certain intensities of hurricanes are more frequent in southeast Florida as well as Dade County. Using the Saffir/Simpson Scale, most hurricanes making landfall in Dade County have been a category two or three storm, as can be seen in the Table on the following page.

${ }^{19}$ Hurricane Procedure P1an, Section I 
NUMBER OF HURRICANES SINCE 1900

BY COUNTY, BY SAFFIR/SIMPSON SCALE NUMBER 20

SAFFIR / S IMPSON

CATEGORY

DADE MONROE BROWARD

1

\begin{tabular}{rr}
1 & 2 \\
6 & 6 \\
6 & 8 \\
1 & 2 \\
$\underline{0}$ & $\underline{1}$ \\
\hline 14 & 19
\end{tabular}

0

$\underline{\text { PALM BEACH }}$ REGION

2

3

4

$\underline{5}$

TOTAL

14

19

4

1

2

$\underline{0}$

7
1

7

3

2

$\underline{0}$

13
3

12

11

4

1

31

Taking the odds in account, a category five hurricane may hit Dade County at an unknown time in the near future.

When asked about the hurricane season in 1980 , Richard

Frank, head of the NOAA said that

- - the chances of a hurricane of any size are substantial. The chances of a major hurricane are less, but nonetheless fairly high. Hurricanes strike the U.S. on the average of about three every two years; a major hurricane strike occurs at a rate of about two every three years... One of the problems right now is that there were fewer hurricanes in the 1970's than in any other decade this century. That gives us a great deal of concern because there could be a resurgence of hurricanes at any time - this year, for instance. 21

However, people should not be concerned whether a hurricane is classified major or minor because even a minor storm can cause tremendous damage. Therefore, hurricane plans should always reflect preparations for the worst possible storm so that any size storm can be effectively dealt with.

20 Ibid.

21 U.S. News and World Report, p. 56. 
F. Response rate to a hurricane warning

There has been a great influx of people into the coastal areas. In 1900 , there were less than 20 million people living near the Atlantic and Gulf coast shoreline; now there are more than 40 million people 1 iving on these coasts. 22 Many of these people have only recently moved to coastal areas and therefore have never experienced a hurricane. They seem to become complacent about the threat of a hurricane. This is probably a result of the fact that there have been fewer hurricanes recently. This complacency might also have lead to the construction of the many hotels on Miami Beach. People always seem to think that something bad will never happen to them, only to others. According to a 1975 National Weather Service survey, almost 80 percent of the 40 million people living in hurricane-threatened areas had never experienced a direct hit by a major hurricane. 23

When a hurricane would actually threaten and a warning is issued, people should act swiftly to evacuate once the warning is received in order to avert a major disaster. Those people who do not promptly react to the warning are trapped by the time the magnitude of the hurricane becomes apparent.

22 "Hurricane Warning!, "People, 29 Aug. 1983, p. 87.

23 Hurricane Survival (Miami: NOAA and National Weather Service, 1984). 
An article in the National Geographic states that

- . since a large proportion of Florida's population has never witnessed a severe hurricane, a warning response rate of less than $50 \%$ can. be expected. Even most police officers, fire fighters and Red Cross people do not know what to do in the event of a disaster. Reactions range from robotlike to hyper-

The Department of Civil Defense also did some studies.

One of these studies indicates that

- - many of the people living on the Florida coast would refuse to evacuate voluntarily in the face of an oncoming hurricane. 25

In 1926, when one of the most violent hurricanes hit

Miami, Mr. Reardon wrote in his memoires that

- - on the way we bought a copy of the Miami Tribune with an eight-column 'streamer' heading giving warning of a tropical storm. Of course, we paid little attention. They appear often here this season of the year. 26

The loss of life is mostly due, not to a lack of warning, but to a decision by individuals to stay despite the warning.

Many people do not seem to realize how devastating a hurricane can be. They think it is just a strong wind that can be easily stopped or destroyed. The United States Weather Bureau receives many suggestions each year from people who are appalled by the annual death and destruction caused by these severe storms. The Bureau claims that since many proposals

\footnotetext{
${ }^{24}$ Funk, National Geographic, p. 374 .

25 Ibid., p. 373 .

26 L.F. Reardon, The Florida Hurricane and Disaster
} (Miami: Publishing Company, 1926), p. 7 . 
have been made for hurricane prevention and all have been impracticable so far, it is evident that most people have little realization of the energy generated and consumed in an average hurricane. One storm can use the energy generated by several atomic bombs! 27

The majority of the people also does not seem to know how a hurricane works. They don't know that only in the eye of a hurricane the winds decrease. For example, as the eye of a violent hurricane passed over downtown Miami, the wind decreased to about 10 miles per hour, while at the same time a hospital on Miami Beach 6 miles away was reporting the wind to be 80 miles per hour. 28

According to Norman Davis, Civil Defense director of Mobile, Alabama, people have to experience a severe storm first before they realize 'this is it!' He says

- . as long as memories of this one (severe storm) remain, I don't think we will have any trouble convincing people to evacuate. Folks just don't-believe wind can get that strong. 29

Mr. Mc Mullen, a hurricane specialist of the Dade County Office of Emergency Management visits many hotels in Miami especially on Miami Beach - to give lectures and advice to

\footnotetext{
27 Dunn and Miller, Atlantic Hurricanes, p. 127. 28 Funk, National Geographic, p. 376. 29 Dunn and Miller, Atlantic Hurricanes, p. 78.
} 
hotel management. He pleads for recognition of the dangers to life along the coast but sometimes he feels he is accomplishing little. "Human behavior is even more difficult to predict than a hurricane," he says, "In some places people hotel-guests as well as other residents - do not want to leave the area. Some hotels right on the beach even had hundreds of people check in to the hotel during the hurricane warnings. People think they are safe in a high-rise building, wherever it may be located. When a major hurricane hits, though, and something serious happens to the guest, the hotel can be held liable for everything." 30

In 1979, hurricane David gave Miami Beach a close shave and a Labor Day scare. The storm just passed off-shore after devastating the Caribbean. A hurricane warning was issued and a lot of people left Miami Beach, looking for safety elsewhere. However, no serious damage was done, so the people who evacuated got mad that they had to evacuate for nothing. An article in the National Geographic described this as follows:

- The real tragedy may be yet to come in Miami Beach. Many people, outraged at being moved for a storm that missed them, vowed to stay put next time.31 People seem to become careless after a while.

30Interview with Mr. Mc Mullen, June 15, 1984.

31 Funk, National Geographic, p. 362 . 
G. Hurricane Probabilities

It is very difficult to predict hurricanes. Mr. Pardue in his book September, Remember says that hurricanes are unpredictable:

- - Sometimes it seems that there are cyclical effects in hurricane paths, numbers per year, and places of formation. One axiom that is useful in keeping us out of traps is 'The moment a cycle is discovered, it is likely to disappear'. 32

Looking at the direction of a hurricane, a probability forecast can be made for a hurricane to hit a specified area. For instance, when a hurricane is 72 hours offshore,the Weather Bureau has on 1 y a $10 \%$ chance of predicting accurately where it will finally come ashore - if it comes ashore at all. Even when a storm is just 24 hours off the coast, predictions are wrong more than half of the time. The following table gives a general pattern of the probabilities that a hurricane will move toward a certain shore. The probabilities describe in percentages the chance that a storm's center will pass within 65 miles of a particular place.

HURRICANE PROBABILITIES 33

HOURS BEFORE LANDFALL

72

48

36

24

12
PROBABILITY FORECAST

less than $10 \%$

$13 \%$ to $18 \%$

$20 \%$ to $25 \%$

$35 \%$ to $40 \%$

$60 \%$ to $70 \%$

32 Pardue, September, Remember...Weatherwatch, p. 13. 33 Hurricane Procedure Plan, Section I. 
Because there is such a short time between a hurricane warning and the actual landfall - a time span of only 12 hours it is going to be very hard to get all people. off Miami Beach within those twelve hours. The only reason for this is the overbuilding in this area. With such an enormous growth on the coast of Miami, and no real good hurricane forecasting, scientists have concluded that they can no longer predict the landfall of a hurricane in time to guarantee that everyone can get out alive. John Byrne, Administrator of the NOAA added to this:

- . If a hurricane strikes this year, it can be expected to hit a population largely inexperienced with hurricane survival, facing inadequate escape time and congested evacuation routes. We are one year closer to a major hurricane, one that could kill thousands of us, especially at the beaches. 34

H. The 1926 Hurricane: an example.

The hurricane that hit Miami in the year 1926 is one of the most memorable ones. It destroyed a lot of properties and caused a great deal of distress to many people. The following is a summary of storm damage in Dade County, with the exception of property damage, as compiled by the Red Cross, dated October 9, 1926 :

34 "Storm Warnings, "Wa11 Street Journal, 14 0ct. 1983 , p. $21, \operatorname{col}$. 1 . 
ESTIMATES OF STORM DAMAGE 35

$\begin{array}{lrrr}\text { AREA } & \text { DEAD } & \text { INJURED } & \text { - FAMILIES AFFECTED } \\ \text { Miami } & 115 & 1,300 & 5,000 \\ \text { Miami Beach } & 17 & 1,632 & 2,000 \\ \text { Hialeah } & 26 & 800 & 1,500 \\ \text { Rural Dade County } & 5 & 40 & 2,000\end{array}$

As can be seen from the table, almost one out of every family on Miami Beach was injured by the 1926 storm. This indicates that Miami Beach is indeed a very vulnerable area. When exploring Miami Beach after the hurricane, Mr. Reardon, a Miami native, observed and wrote the following in his memoires:
- We proceeded through scenes of desolation to South Beach. Here is where the gale did its worst. Most buildings and hotels were condemned or twisted into an unrecognizable mass. Not one hotel escaped the ravages of the storm... So clean was the sweep of the torrent through the ground floor of the Roney Plaza Hotel that not a little testimony remains, that only two days ago there were here dozens of shops, beauty parlors and drug stores... Sand of the beach was two feet deep two hundred yards west of the ocean. It seems the entire beach line has been moved a block west. 36
This is a very vivid description of the bad shape Miami Beach was in. And there were not even half as many hotels on the Beach as today!

35 Reardon, The F1orida Hurricane and Disaster, p. 110 . 36 Ibid., p. 72 . 
Winds of the 1926 hurricane reached 140 miles per hour, and storm surges left Collins Avenue and Mac Arthur Causeway inundated - eight feet of water washed out the Causeway! Storm surges with hurricane waves of up to 15 feet killed more than a hundred people in Miami and Miami Beach.37

\section{Storm surge}

The storm surge is the killer element in any hurricane. 38 Essentially, it is an enormous dome of water, perhaps 50 miles wide, and when it hits - sometimes traveling miles inland in low-lying areas like Miami and the Beaches - it can be as devastating as a tidal wave. A hurricane may release torrential rains with six inches of rainfall and winds of up to 200 miles per hour, but nine out of ten deaths are caused by the storm surge. The shallower the water is, the higher the storm surge will be. In areas that are subject to predictable flooding and wave damage all people should evacuate since their safety cannot be guaranteed. The Office of Emergency Management in Dade County says that all residents east of Collins Avenue (on Miami Beach) are in imminent danger from hurricane storm tides (Zones 2 through 7 , see Figure 2.3 on next page). The more severe the hurricane, the more intense the threat to 1 ife. All residents in Zone 1 through 7 which are east of the intercoastal waterway should evacuate in any hurricane. 39

37"The 1926 Hurricane;"The Miami Herald, 7 June 1964 , Section $H, p .1$. ${ }^{38}$ people, p. 87. 
A publication of the NOAA also states that the storm surge is the most dangerous part of the hurricane. In this publication it is said that the threat of a hurricane to us occurs in the following order: storm surge, the storm's worst killer; wind damage, and the possibility of associated tornadoes; and inland flooding. The storm surge is capable of smashing structures to rubble, eroding long stretches of beach, and undermining anchored buildings. Florida's hurricanes have brought storm surges of 15 feet or more above sea level, so the hazard to Miami Beach is extreme. While storms with high tides are rare, they are possible in any hurricane season. 40 All Floridians in coastal areas - home-owners and hotel-owners alike - should make this extremely dangerous possibility part of their hurricane planning.

Dunn and Miller in their book Atlantic Hurricanes say the following about the storm surge:

- . The hurricane tide alone may result in extensive damage to all buildings along the coast. Only wellconstructed and well-anchored buildings are usually able to withstand the rise in the water level, the main damage being done to furnishings, plaster, etc.41 Recently, in the Miami Herald, a scenario was written on what could happen when a Category Five storm would make landfall at Miami Beach:

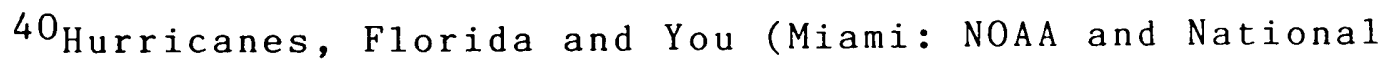
Weather Service, 1984).

${ }^{41}$ Dunn and Miller, Atlantic Hurricanes, p. 220. 
- A storm surge will inundate coastal areas with a tide of 17 feet or more. Pounding waves will slam against the first and second stories of buildings lining the beaches. Some of those buildings will topple. The waves will pick up what is.left of them and batter the buildings that still stand.42

From whichever viewpoint we look at the storm surge we can conclude that ignorance of these storm surges will cause a lot of damage and cost many lives.

\section{J. The 'Hurricane' Building Code}

One should not begin to prepare for a hurricane the day before it strikes, or a week, or even a month. Complete preparations require careful planning years in advance.

Since the late twenties communities along the Southeast Florida coast have adopted strict hurricane building codes for all types of buildings. Buildings erected in conformity with these codes are withstanding the hurricane winds without serious damage. There are still many old buildings, however, that have not been renovated yet with the proper materials. Such structures will continue to suffer damage. 43 There is no question that the modern building codes are paying off in greatly reducing property damage whenever they are properly enforced.

42"Hurricane Preparedness, "The Miami Herald, 19 July 1984, Sec. HA, p. 3 .

43Dunn and Miller, Atlantic Hurricanes, p. 236. 
The South Florida Building Code affords protection from the winds in an 'average' hurricane, which is considered to be a Category Three hurricane with winds of 110 to 130 miles per hour. For example, the 100-mile-per-hour sustained winds of 1964's hurricane Cleo seriously damaged fewer than a dozen Dade County roofs. On the other hand, many structures built to hurricane specifications will be damaged by winds as strong as those which struck the Florida Keys a generation ago with winds of over 150 miles per hour. Fortunately storms of such violence are rare, and building codes to protect against them are probably not justified from an economic standpoint, i.e. when protection costs more than the value of the lost property. Nothing can be built to withstand the awesome power of winds of 150 miles per hour of higher. Even inland areas will not escape the destruction of a Category Five storm. 44 Some authorities say that, in spite of the hurricane building codes, rapid development has caused shoddy construction in hurricane zones, and that some of these new buildings might not stand up to a large storm. Dr. Frank of the NOAA confirms this. He says that

- . some individuals have built in areas where a storm surge has totally wiped out buildings in the past; others have built in front of dunes rather than behind them. They often have failed to use pilings, which are very important, or they have built in other ways that are fragile.45

${ }^{44}$ The Miami Herald, Sec. HA, p. 3 .

45 U.S. News and World Report, p. 56. 
Some examples of bad construction are quoted in the book Atlantic Hurricanes: ${ }^{46}$

1. Inadequate connections between foundations and sills.

2. Inadequate reinforcements of building foundations and piers.

3. Improper anchoring of roof and ceiling framing to side walls.

4. Insecure attachment of roof coverings and sidings.

5. Weakness of concrete.

6. No installation of shutters to cover glass windows.

7. Broad roof overhangs.

8. Flat roofs.

Despite all warnings, developers continue to crowd the coast, and often refuse to compromise with the giant storms.

\section{K. Evacuation}

We should ask ourselves why much of the building is done without adequate means of evacuating the area efficiently when a storm warning is issued. Money spent on warning system development is wasted if people are allowed to live or vacation in vulnerable places without adequate means to escape when danger threatens.

Evacuation of people is becoming more and more of a problem all the time as a lot of residents flock to our coastline. Warning the public for an oncoming hurricane becomes a problem since questions of accuracy always remain. It is the goal of the Hurricane Center in Miami to warn the public in time to give twelve hours of daylight to prepare for a hurricane. 47 Experience has shown that this much time is necessary

46 Dunn and Miller, Atlantic Hurricanes, p. 237. 47Peter Briogs. Rampage (New York: David McKay Co., Inc., 
to secure property and evacuate residents from exposed areas. But the more people live in these areas, i.e. the beaches, the harder it gets to evacuate them. Parts of Miami Beach are linked to the mainland by only a few low bridges. Rising water could block these spans 12 to 24 hours before the hurricane winds come in. In a panic evacuation these bridges could be closed quickly by auto wrecks or the heavy waves of storm tides. 48

The Wa11 Street Journal states in one of its articles that

- with nearly half a million people in South Florida vulnerable to a big storm, evacuation time itself is estimated at 21 hours, with six to twelve, hours beyond that required to get the process working. 49

If this is the case then a warning 12 hours in advance would not do much good to the people who have to evacuate. A lot of coastal residents will then choose not to evacuate because they know that the odds are good that they don't really have to. They don't want to go through the inconvenience of evacuation of there is still a $30 \%$ probability that they can stay home safe. 50

Residents on Miami Beach should get away from the beaches or other locations which may be swept by high tides or storm waves. Hotelguests should be advised to leave the area or to

48 White and Has, Assessment of Research on Natural Hazards, p. 3 .

$$
{ }^{49} \frac{\text { Wa11 Street Journal }}{\text { Ibid. }}, \text { p. } 21, \operatorname{col} .1 \text {. }
$$


evacuate the first two floors of the hotels where the ocean water can still reach them. 51

Dr. Frank, Director of the National Hurricane Center, often travels the Atlantic and Gulf coasts, preaching preservation of beaches, tougher building codes, and better avacuation procedures. He favors 'vertical evacuation' - moving people into the tallest, soundest structures that are farthest from the beach, thus escaping storm surges that can exceed 25 feet. 52

White and Haas in their research have other ideas about this vertical evacuation. They say this concept is

- - an increasing possibility with new construction, but it is limited by space and the willingness of owners to allow public access to their private property. 53

People have to be made aware of the dangers of a hurricane. The NOAA has worked on storm surge plans for Dade County that tell what areas would be inundated when the storm surge hits and what roads would be available for evacuation. Everybody should know these plans, especially the hotelmanagers of Miami Beach hotels who work in an exposed area and could be held liable for the guest's life and property. 54

${ }^{51}$ Dunn and Miller, Atlantic Hurricanes, p. 238.

52 Funk, National Geographic, p. 374 .

53 White and Haas, Assessment of Research on Natural Hazards, p. 33 .

54 U.S. News and Wor 1 d Report, p. 56. 
A number of psossible events could preclude successful evacuation of the entire Miami Beach population. White and Haas state the following problems in their research:

- . First, not all of the 12 hours of warning are available for evacuation... Storm surge may cause tides to rise as early as six hours prior to a hurricane's landfall, thereby flooding the roadways used for evacuation.

The drawbridges represent another weak link in the escape route. Rising winds and heavy seas contribute to the probability of the drawbridges to fail and lock in the up position.

Evacuation by sea is too dangerous and evacuation by by air is precluded by the lack of an airport and the danger of utilizing helicopters in high winds. 55

It is therefore of utmost importance that Miami Beach residents evacuate as soon as possible after a warning has been issued. Rush hour traffic today probably represents less than $40 \%$ of the traffic which could be expected with a warning to evacuate, and even this amount cannot be accomodated without major delays. 56

Evacuation remains a difficult problem because needless evacuation is costly and because failure to evacuate can be tragic.

55 White and Has, Assessment of Research on Natura1 Hazards, p. 32 .

56 Ibid., p. 33. 
L. Preparation for a hurricane

In some cases of disaster there will be advance warnings of such incidents to permit precautions to be taken. At other times the incident can occur without warning. Hotels must be prepared to do whatever is necessary to protect property and provide for the safety of all persons within the hotel. The best should be made of a bad situation, and it should be done before disaster strikes. There are many things that could be done to prepare for a hurricane. According to Buzby and Paine disaster planning should include

1. Special supplies.

2. Provisions for housing and feeding employees unable to leave the building due to weather conditions.

3. Fresh water supplies.

4. Provisions for emergency lighting.

5. Various degrees of action to be taken should be spelled out.57

The authors go on say that the provisions to notify guests in the event of a hurricane and the instructions available to insure that guests react in the proper manner should be reviewed. Whatever is done should be accomplished calmly so as not to disrupt normal operations ar cause concern among the guests. Only when a hurricane actually strikes should the guests be kept informed of what the dangers are in case they want to leave the hotel or the area. 58

57Walter J. Buzby and David Paine, Hotel and Motel Security Management (Los Angeles, California: Security World Publishing Co., Inc., 1976), p. 187 .

58Ibid., p. 189 
In preparing the hotel emergency plan, the elements outlined below should be included, as a minimum, in the basic plan:

1. Authority and Personnel

This section should include reference to company key personnel which will authorize an emergency plan; the organization of an emergency staff and the designation of an emergency manager. Ca11-up lists of key personnel and alternates will be useful. These 1 ists should include names, positions, addresses, phone numbers and operational responsibilities for emergency operation. Organizational charts can also be helpful before and during emergency operations. Responsibilities of the emergency staff should be shown.

2. Plans of execution

The basic plan should provide for coordination of company and government actions before and during a hurricane... Within the property, the responsible official is part of management... He is to place the emergency plan into effect.

3. Supporting information

Plans and maps: Hotel facilities as well as street and other relevant maps should be available. Records of inspections, corrections, drills etc. Listing of local resources: Major sources of additional manpower, equipment and supplies.

Glossary of terms: To be effective, the basic plan should use terms that mean the same thing to everyone concerned. 59

Emergency plans need to be spelled out, otherwise things may never get done. If a plan is written well, it is a tool that will help everyone protect his job, his paycheck - and perhaps his life. The hurricane plan should unite on-duty hotel personnel with volunteer groups such as Bi11, 1980 . 
the Red Cross, the Weather Bureau, the Coast Guard, hospjtals, private utilities, and various federal agencies. Emergency plans should always be updated and should become part of standard operating procedures and good management, as it can great 1 y affect the loss of lives and property which could occur in natural disasters. 60

Protection of the hotel's assets and its guests is the prime concern in an emergency situation Burstein in his study says:

- In al1 cases where buildings are to be vacated, assets must be secured and guests and their property should be protected. For example, housekeeping personnel should see to it that all guestroom doors are locked when the guests have been evacuated.61

The Emergency Bill states that the following records should be well protected in case of a hurricane:

"1. Names, addresses and phone numbers of all employees. 2. Names, addresses and phone numbers of concessionaire.

3. Payro11 records.

4. Accounts Receivable.

5. City Ledger.

6. Guest Room Accounts.

7. Valuable Papers and Documents.

8. Names, addresses and phone numbers of all suppliers and purveyors. 62

In the case of people coming to the hotel to seek refuge, general managers must decide first if it is safe enough for the people to stay in the hotel at all. If it is declared

$60_{R}$. Marvin Townsend, "Hurricanes: Tracking Many But Knowing Few, "Public Management, Jan/Feb. 1981, p. 2 .

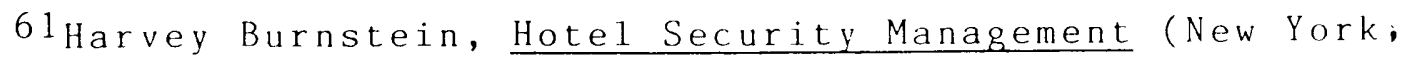
NY: Praeger Publishers, 1975), p. 118.

$62 \ldots-\ldots$. Emergency Bi11, 1980. 
safe, Burnstein writes, the manager must carefully evaluate the number of persons that the hotel can accomodate for a given period of time in terms of housing and feeding. He further suggests that no alcoholic beverages be served, to avoid the creation of more tension. There should also be an increased patrol activity and all arrivals and departures should be supervised. 63

When hurricane Alicia struck Houston, Texas, most hotel properties voluntarily sacrificed revenue in order to aid the thousands of local residents left homeless by the hurricane:

... the homeless were able to keep their accomodations 'as long as necessary'...and the properties dug into their food reserves to offer both a free lunch and a free supper buffet. 64

As the Hyatt Regency General Manager explained: "We sympathize with people who have nowhere to go."

Some of the basic things that should be done in a hotel when a hurricane watch is received are as follows: 48 hours before landfal1: Check storm shutters. Take patio furniture inside. Throw pool furniture into pool. Take furniture out of first and second floor rooms. Remove furniture from balconies. Check food supplies and other supplies such as flashlights, batteries, candles, etc.

63 Burnstein, Hotel Security Management, p. 118 .

64 Sharon Donovan, "Hurricane Alicia Checks In, "Hotel and Motel Management, Oct. 1983, p. 3 . 
36 hours before landfall: Put up storm shuters. Tape windows where necessary.

24 hours before 1andfal1: Advise guests of situation and make arrangements for accomodations elsewhere if necessary. Fill one dozen bathtubs with fresh water to be used for drinking and cooking purposes if necessary . 6 hours before landfal1: Check if all loose objects are removed from outside. On 1 y authorized personnel is to stay in the hotel.

2 hours before landfa11: Open one front door. Check all windows to make sure they are secured. Open connecting doors in rooms. Lock elevator up on the top floor. Set up an emergency post. 65

There is one more thing that should be taken into consideration when operating a hotel in a hurricane-prone area: insurance. Insurance is said to be just one important element in a program called risk management. Donna Jackson describes it as follows:

- Insurance alone is not a complete remedy. That's why risk management - a system in which you take steps to control losses and minimize the consequences of $10 s-$ ses when they do occur - is being increasingly employed. 66

She goes on to say that risk management consists of six steps which are identifying the risks, evaluating the risks, risk control, risk financing, evaluating the program, and monitoring the program. The insurance comes in when the risks are

65 Adapted from Emergency Bi11, 1980.

66 Donna Jackson, "Risk Management: What You Don't Know Can Hurt You," Foodservice Marketing, Sept. 1982, p. 54. 
being identified, i.e. Business interruption- and flood insurance could be purchased when dealing with the risk of a hurricane. This should always be done well in advance!

There is a lot of planning required before a hotel can ride out a hurricane without too much damage and loss of 1ife. Although it is very important to have an emergency plan in case of a hurricane, many hotels do not prepare themselves well enough for the hurricane season because they are so "caught up in all their day-to-day problems."67 one day they might have to pay for it!

\section{SUMMARY AND CONCLUSIONS}

Hurricanes have always posed a formidable threat to mankind but it appears that nowadays a larger number of people are aware of a hurricane's occurrence. The modern catastrophe is better reported than in the past. Due to protective measures adopted by state and local governments and by private agencies such as the Red Cross, a better-informed public, and an improved warning service, the average death toll has dramatically

67 Funk, National Geographic, p. 375. 
decreased, although hurricane damage is not boing greatly reduced over the years. It is the continuing trend of urbanization that still poses the dangers, though. On one hand, in the case of a growing agglomeration - both property and population - the latter remains mobile and can therefore escape certain hazards. On the other hand, the greater the population is the greater will be the target for the violent acts of God. It is hoped that a major hurricane will never strike Miami Beach, of course, but it is better to be prepared and to know exactly what is to be done and who is responsible for doing it, than to wait until the last minute and be forced to take action in a confused and inefficient manner. From the related literature I can conclude that there is still a lot of ignorance when it comes to hurricane preparation in hotels. And that creates a scenario for what could be the worst disaster in history, especially on Miami Beach. 
CHAPTER III

GENERAL PROCEDURES 


\section{C.HAPTER I I I}

\section{GENERAL PROCEDURES}

\section{A. The Data}

Two types of information sources that will be used in this research are primary data and secondary data.

\section{Primary Data}

Primary data are data that are either observed and recorded or collected directly from respondents who are closest to the phenomenon. ${ }^{1}$ In this research the primary data include include information gathered from personal interviews with at random chosen general managers and security personnel in Miami Beach sea-front hotels. Rapport through direct interaction usually permits more in-depth interviewing, including probes and follow-up questions. Reasons for non-response can also be better explored.

Before the personal interviews will take place, a written questionnaire will be sent by mail to the selected persons discussed above.

\section{Secondary Data}

The secondary data are the data that are compiled without direct help of respondents. They are somewhat distorted by communication, i.e. different writing and reading skills. Secon-

lWilliam M. Pride and 0.C.Ferrell, Marketing, Basic Concepts and Decisions (Boston: Houghton Miffin Company, 1980), p. 82 . 
dary data in Lhis research include materials laken from buoks, articles, periodicals, university publications, publications of various associations, hotel manuals, speeches, and unpublished sources.

B. The Criteria Governing the Admissibility of the Data.

Only sea-front hotels on Miami Beach will be taken into consideration in this study. Responses of all managers, security personnel, and any other employees will be evaluated in the same manner, regardless of how long these people have been working in their particular hotel. Responses from recognized people working in the field of hurricane preparedness in Miami will a1so be considered.

Al1 secondary data was taken from material written by experts or other recognized persons in the field, and the sources were reliable, i.e. we11-known magazines, scientific periodicals, and published and unpublished material from local or national organizations experienced in the field.

\section{The Research Methodology}

Research methodology is merely an operational framework within which the fact are placed so that their meaning may be seen more clearly. 2

${ }^{2}$ Paul D. Leedy, Practical Research: Planning and Design (New York: MacMil1an Publishing Co., Inc., 1980), p. 75. 
Data are either in the form of writing or in the form of observations. In this study both forms will be used. Written historical data and critical data were gathered in order to form a background to the problem at hand.

Observations will be used in the form of personal interviews and the responses to the questionnaires. Data derived from observational situations, whether these are physically observed or "observed" with the help of a questionnaire, are dealt with appropriately in the descriptive method. ${ }^{3}$ Therefore, the researcher decided to obtain the necessary data by use of this method. Questions were designed to obtain information that meets the data requirements of the study. The information provided by the questionnaires will be recorded and will be used in deciding whether to accept or reject the hypothesis made in this study. Results from personal interviews with hotel personnel will also be used in this decision-making process.

\section{The Questionnaires}

The problem outlined in Chapter I of this research project focused upon the identification of the degree of hurricane preparedness in selected Miami Beach hotels. A questionnaire was designed to be answered by General Managers or Security personnel of these selected hotels. A copy of of the questionnaire is included in Appendix E. 


\section{E. The Subjects}

The subjects regarded most suitable by the researcher to answer the questionnaire were the General Managers of the hotels. Managers are probably most knowledgeable about the existing plans and operations of the property. Therefore the questionnaire and a cover letter were initially sent to these managers. (Copy of cover letter is included in Appendix D).

As the delimitation in Chapter I mentions, only hotels with 150 rooms or more were selected for this study. There are only twenty-four (24) sea-front hotels on Miami Beach that comply with this delimitation.

After all the names of these hotels were compiled, they were each given a phonecall to find out what the General Manager's name was. During this process it was discovered that three of the properties were not open at all for the season. This reduced the total number of subjects to 21 . Thus, the questionnaire was sent to 21 hotel managers.

It was felt that the best method of obtaining the desired information would be to have the managers fill out the questionnaires at their leisure (they were given approximately two weeks time), after which the researcher would make a followup phonecall in order to make an appointment for a personal interview and to pick up the questionnaire. When these follow-up phonecalls were made two weeks later, only 15 of the 21 hotels were willing or able to accept a personal interview. The other six either preferred to return the questionnaire by mail (which 
they never did) or they claimed they didn't have any information to disclose. Therefore, the final results are based on the answers of only 15 subjects.

Not al1 questionnaires were answered by General Managers. In some cases, the questionnaire was filled out by the Comptroller or the Director of Security, depending on the organization of the hotel. An analysis of the respondents who answered the questionnaire showed that $66 \%$ were General Managers, $14 \%$ were Security personne1, $14 \%$ were marketing and operations managers, and $6 \%$ were comptrollers. Most of these respondents had been working ot their particular properties for quite a long time: 5 to 27 years. Only three persons had recently started working at their property. However, they a 11 seemed to know the necessary information about hurricane preparedness in order to fill out the quesitonnaire.

\section{F. The Treatment of the Problem}

\section{Data Needed}

The data needed for the treatment of the problem are the responses to the interviews and questionnaires provided by the General Managers and the other respondents in this study. Other data needed are the secondary data derived from the related 1iterature and available information from safety manuals in the hotels. 


\section{Location of the Data}

The data are located in the responses of the individuals to be interviewed and in the responses to the questionnaires. The information to be extracted from the various hotel manuals is located in the responsible department within the hotels.

\section{The Means of Obtaining the Data}

The data will be obtained through personal interviews with the indicated employee groups and with the help of questionnaires. The selected hotels will be introduced to the proposed study by means of an introductory letter. Follow-up phone calls will be made two weeks later to make appointments for the interviews with the selected persons. The questionnaires and any written material from the safety manuals will be collected at the time of the interview. The data will be secured by accurately recording all of the responses of employees to the questions on the questionnaire and in the interview.

\section{Treatment and Interpretation of the Data}

Each questionnaire will be screened immediately after it has been filled out, so that mistakes or ambiguities can be discussed rightaway. This will hopefully lead to more correct and valid answers. Additional questions - not on the questionnaire - may be asked and discussed, if necessary.

From the responses of the questions frequencies of each 


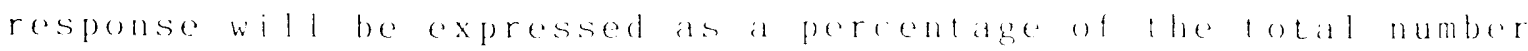
of that same response. The outrome of each question will then be discussed in relation to the problem. Finally, the decision will be made whether to accept or reject the hypothesis made in this study. 
CHAP'LR II

THE RESII,T'S

The results of the survey will be presented in this chapter, the conclusion of which will relate such results to the hypothesis made in Chapter I.

\section{A. Discussion of Responses}

Al1 subjects were asked to respond to the questionnaire designed to determine the degree of hurricane preparedness. To facilitate responses, most questions were asked in such a way that a simple checkmark could be used to answer "yes" or "no", or similar short answers. Because this demanded only two minutes of their time to fill out the questionnaire, most subjects were generally found to be very willing to help.

The discussion of the results will be presented as fol-

\section{lows:}

1. A short explanation will be given why that particular question was asked or why it is important.

2. The answers to the questions will be given in percentages and will then be discussed in light of the problem.

3. The answers to additional questions not on the questionnaire will be discussed.

The first question on the questionnaire was asked in order to find out whether the hotel had indeed 150 rooms or more available. All the hotels in this study complied with this de- 
limitation so no problem was encountered with invalid questionnaires.

Question two was asked because it is interesting to know when these hotels were built, in connection with several severe storms and hurricanes. All hotels in this study were built between 1938 and 1962, which is after 1926 and a1so after 1950, the years that Miami Beach was damaged extensively by some of the strongest hurricanes in history. The fact that people started building again only a few years after these hits is amazing. It proves that people forget bad things fast and don't expect them to happen again in the future.

The third question was asked to find out who completed the questionnaires. In other words, who felt most knowledgeable about the subject. It was also helpful for later referral in case the researcher needed to contact the respondents for further information.

The next question, number four, refers to the length of time the respondents have been working in their particular hotels. Although all answers were taken into consideration, it could be assumed that some of the respondents who have only worked at their hotel between three months and one year, probably did not fill out the questionnaire as accurate as possible, for the simple reason that they were not that familiar with the emergency procedures as yet.

Question five is thought to be a very important question. It asks if the respondents have ever experienced a major hurricane. The answers to this question can be considered as a 
first indication of how well a hotel is prepared for a hurricane. In other words, if the manager or owner himself does not see any harm in a hurricane on Miami Beach, his hotel will most likely not have a very extensive hurricane prevention plan either. Some kind of correlation seems to exist between these two facts. This was supported by the results of the questionnaires. Of all respondents, only $33 \%$ had experienced a major hurricane; $67 \%$ had either experienced a mild storm or none at all. This confirms the fact that the majority of people living and working in coastal areas do not realize what a real hurricane can do in terms of damage. None of the respondents who had experienced a major hurricane, had experienced one on Miami Beach. Orlando, Daytona Beach, Louisiana, and Texas were mentioned as being the places of landfall by most respondents. These people learned from their experience because now they all adopted some kind of hurricane prevention plan in the hotel they are currently working. The sincere interest and complete support of top management are indeed essential if an emergency plan is to be set up in an effective way. In question six, the subjects were asked what their responsibilities would be in case of a hurricane. This question was included to see if respondents indeed had any responsibi1ities and how they would perceive these in their minds. The answers to this question were very varied. Thirty-six percent (36\%) of the subjects reported that they had no responsibilities at a $11(!)$, whereas $64 \%$ of them stated one or more of the following responsibilities: coordinate preventive maintenance 
action plan; secure the building and implement hurricane safety precautions; advise, monitor and respond; or coordinate safe evacuation of guests and employees with executive management. Questions seven and eight deal with emergency "key personnel". In any emergency, there have to be key people available for work or for help. It is hard to assign these people at the moment the emergency strikes. On Miami Beach, the hotels should know in advance whom they can rely on, where these people can be reached, and what they are to do in case of a hurricane. It should be part of the hurricane preparedness plan. Therefore, two questions on this subject were included in the questionnaire. The majority of the subjects interviewed (86\%) claimed that key personnel is indeed assigned, $7 \%$ said no assignments were made, and another $7 \%$ said that employees would volunteer in case an emergency arose. Al1 respondents, however, reported that they have some kind of 1 ist with al1 names, addresses, and phone numbers of employees available in case they were needed.

Question number nine was asked to find out whether the hotel had insurance coverage relating to a hurricane. All answers were in the affirmative. However, most insurance policies only included reimbursements for flooding (as a result of a hurricane), and nothing for wind or other rain damage. When the respondents were asked what they would do to protect the hotel, its guests and its employees in case of a hurricane, three of them answered that insurance was the only protection they had and that they relied on it. No preventive measures would 
be taken at the time of a hurricane warning because "the insurance will pay for all the damage anyway". This is a rather passive way of entering the hurricane season on Miami Beach! The results of the next two questions are as follows:

$\begin{array}{lll}\text { Emergency lighting and } & \text { Yes } & \text { No } \\ \text { electricity available? } & 73 \% & 27 \% \\ \text { Maps of hotel available? } & 67 \% & 33 \%\end{array}$

Since water, light and power for use during a hurricane will be essential for the protection of the facility and its guests, plans should be made to provide for a secondary source. This secondary source will often be vital because the normal sources may be disrupted by the emergency conditions.

Maps of the hotel and a lay-out of the rooms and the emergency exits are also important, especially when evacuation has to take place fast. Most of the hotels seem to have both the secondary water, light and power sources and the hotel maps. The others, however, still need a lot to work on if they want to protect their guests and their property in the best possible way before and during a hurricane.

Another interesting question where most of the hotels differed in their answers was the one inquiring about the protection of the hotel's records, such as payroll, accounts receivable, guest history, vendor 1 ists, etc. This question shows how much the hotel really cares about its records (and therefore its business!). Vital records should be duplicated and stored at an off-site location. Cash and other valuable 
items should also be protected. This is not what most hotels do, however. Seventy-one percent (71\%) of the subjects answered that there is indeed a list of vital records that should be protected in case of a hurricane. What is actually done, however, is as follows:

Send to corporate office weekly

$13 \%$

Send to top floor of hotel

$20 \%$

Put in safe

$7 \%$

Nothing/ Let them get wet

$27 \%$

Not specified

$33 \%$

Four of the hotels did not have a list of vital records. Two of these even claimed they did not have any vital records worthwhile to keep in case of an emergency, such as flooding. The operation of some of these hotels seems questionable.

Question thirteen was asked to see if management knew where to get all its extra supplies and equipment in case the hotel would have to serve as a refugee center. Because Miami Beach is a very vulnerable area, only connected by a few bridges, it is important that "refugees" can be provided for in a reasonable manner. A11 respondents in this study claimed that they knew enough people and businesses that could supply them with the necessary manpower, equipment and supplies. However, in $86 \%$ of the hotels this was not put down in writing, so in case of an emergency this can still create a chaotic situation. With question fourteen the researcher wanted to find out what kind of alarm system the hotel uses to warn the guests and the employees for a hurricane watch. A means of rapidly trans- 
mitting a warning of an emergency condition is a vital element in any disaster plan. Arrangements must be made to transmit a warning as quickly as possible. The amount of advanced notice given might be very valuable in terms of avoiding casualties and in limiting the damage to the facility. Whereas $33 \%$ of the hotels use their fire alarm to warn people for a hurricane, $20 \%$ of them installed a separate warning system in terms of a blue, a yellow, and a red alert, used depending on the severity of a certain emergency. Another $20 \%$ of the hotels use what they call the "manual system". This includes letters of warning sent out to each guest room, warnings over the phone, and communication through news reports or bulletin boards. The remaining $27 \%$ of the hotels do not have any particular warning system at all. They take it the way it comes or let the guests find out for themselves that they are in an emergency situation. It is the researcher's opinion that the latter is highly irresponsible on the part of these hotels. If they receive guests they should provide for the reasonable safety of these guests.

With regards to written safety measures to protect and guide the guests in case of a hurricane, $50 \%$ of the hotels do have either a simple statement or a very extensive letter that explains to the guest what the situation is before or at the moment of emergency. The Director of Security at one of the hotels even had a letter of this kind translated into five foreign languages in his file! This would be a good example for the other hotels who do not have any written safety measu- 
res at a 11 .

Question sixteen touches somewhat on the legal part of the hospitality industry. The question is raised whether people should be allowed to check into the hotel after an official hurricane warning has been issued by local authorities. Seen from a legal standpoint the answer is "no" but most hotels in reality do not refuse entrance to arriving guests or refugees, even though the potential danger in sea-front hotels is considerably greater than in hotels on the mainland. Fifty-seven percent (57\%) of the respondents say that people are indeed allowed to check in after a hurricane warning has been issued but they also claim that it is the guest's own responsibility if he wants to stay in the sea-front hotel. Another claim was that authorities sometimes order the hotel to remain open and serve as a refugee center for stranded or evacuated people. This on 1 y happens when the hurricane is not a main threat to Miami Beach, however. It is also done because the refugee centers on the mainland are equipped to handle evacuees for on $1 \mathrm{y}$ about two days before the food starts running out.

Question seventeen ties in with the previous one. Hotel management should at least consider it to be one of their duties to warn or advise the guests to evacuate. The final decision is up to the guest. Advise to evacuate is given in $60 \%$ of the selected hotels. The other $40 \%$ do not bother telling their guests anything about evacuation. Seventy-two percent ( $72 \%$ of the respondents claimed they themselves would not leave the ho- 
tel until everybody was evacuated. The remaining $28 \%$ explained that they would or would not leave, depending on the circumstances, i.e. severity of the storm, number of guests in hotel, possibility of getting out via evacuation routes. A copy of an evacuation notice by the Governor is shown in Appendix J.

Because the Dade County Office of Emergency Management assured the researcher that they were giving speeches on hurricane prevention in all Miami Beach hotels, questions nineteen and twenty were included in the questionnaire to find out whether the selected hotels had indeed received any information from this Office. Of the total of fifteen hotels interviewed, $86 \%$ were aware if the information given out by the Office, but on 1 y $40 \%$ had received instruction, either by mail or by means of a speech or slide presentation. Fifty percent ( $50 \%$ ) of the hotels had never received any information or advise, and $10 \%$ had never even heard of the Office of Emergency Management or did not know whether any information was sent to their hotel. Eighty percent ( $80 \%)$ of management at the hotels that had received instructions have acted upon these instructions. Twenty percent ( $20 \%$ ) did not. It was therefore felt that the Office of Emergency Management does indeed encourage or help most of the hotels in developing a hurricane prevention plan by distributing useful and valuable information and giving hints.

One of the most important questions in the questionnaire is question twenty one. It asks in a straightforward manner 
whether the hotel in question has a written emergency plan with details for all departments of the hotel in case a hurricane threatens. The answers to this question probably reflect to the greatest extent the degree of actual hurricane preparedness in each hote1. Although the existence of such a plan does not guarantee the implementation of this plan, it certainly is a step in the right direction. Only $40 \%$ of the selected hotels reported to have some kind of written emergency plan, varying from a one-page fact sheet to a fifty-page thick manual. All employees, or at least all departments in these hotels, seemed to be aware of the existence of the emergency procedures in their hotel,as the $100 \%$ mark shows in the second half of question 21 . The researcher requested permission to look through or to copy some of the hurricane prevention plans that were available at the above mentioned hotels. Most interviewees were willing to hand out a copy of their plan. Two hotels refused to make their plan public because of the confidential information it contained. These were the hotels with the most extensive emergency preparedness procedures. However, the researcher was given an opportunity to look through these plans during the interview, and was able to get some valuable information by simply looking at the Table of Contents of these manuals. A copy of one of these Tables of Content is shown in Appendix F. Copies of other hurricane precautionary guides and manuals are included in Appendices $G$ and $H$. 
Continuing with the last two questions on the questionnaire: $93 \%$ of the subjects felt that the hotel they worked in did comply with the South Florida "hurricane"-building code, and $87 \%$ of these people believed that their hotel was checked for deficiencies in construction etc. at least once a year. These questions are important because from the answers one can deduct how the General Managers and other management personnel think about the condition and the maintenance of their hote 1 .

Some additional questions that were asked during some of the personal interviews cover the following topics: testing the plan, keeping the plan current, security protection, medical aid, and refuge in the hotel.

Testing the plan: The effectiveness of an emergencyplan should not be determined for the first time during an actual disaster. In order to ensure that the plan will be effective under actual disaster conditons, it should be thoroughly tested under simulated emergency conditions. If this is done, deficiencies will be highlighted. Also, very valuable training will be received in reacting under simulated emergency conditions. Of all the hotels interviewed, none of them had ever done any evacuation drills or had tested any other part of the plan! Therefore it can be stated that none of the plans has been proven to be real effective as yet. 
Keeping the plan current: After the hurricane prevention plan has been fully developed, it will be necessary to examine it constant 1 y to keep it up-to-date. For example, changes of personnel involved in the administration of the program or changes of activities within the hotel should, in particular, be noted. Eighty percent( $80 \%)$ of the hotels that reported to have a hurricane preparedness plan, claimed this plan was updated yearly by the General Manager or the Director of Security. Names, addresses, or phonenumbers had to be changed periodically, and recommendations of several local agencies, such as the Red Cross or the Office of Emergency Management, would have to be taken into consideration, according to one of the respondents. Appendix I shows some exerpts from a letter that the American Red Cross sent to one of the hotels. It mainly consists of recommendations for hurricane planning in this particular hotel. It could also be applicable to other hotels on the Beach, though.

Security protection: Security measures must be considered an important factor in any plan to deal with emergencies. Hotels should be prepared to provide complete protection for the facility and its guests. Security controls before or during a hurricane should be designed to protect against loss or damage by employees, guests, or other visitors who are motivated to get into the facility with intent to cause problems. Only seven of the fifteen hotels had a full-time security staff working for them. This is about $46 \%$, a rather 1 ow number! 
Two hotels had one part-time security guard, and the remaining six hotels did not have any security at all. This means that at the time of an emergency the manager or his assistant have to do all the controlling and spying themselves, i.e. watch the lobby, the front door, the hallways, and the rooms at the same time. This would be an almost impossible task! The hotel could also be held liable for whatever happens to the guests when there is no reasonable security in the hotel.

Medical aid: The question was asked whether any of the hotel employees were trained in first aid procedures. The majority of the respondents $(60 \%)$ stated that at least one person in each department knew how to apply first aid, CPR, etc. The other $40 \%$ of the hotels would simply call a doctor or transport the victim if first aid was needed. Again, these hotels might put themselves in a dangerous position by doing this.

Refuge in the hotel: Most guests will not leave the hotel at the time of a hurricane warning, according to one of the General Managers. And they cannot be forced to leave either. Therefore a lot of hotels have designed and designated certain rooms in the hotel to be "safe", i.e. no windows, away from the sea, close to the kitchen, and on the second floor or higher. Ballrooms were mentioned as being the most ideal rooms because of their size. Nine of the hotels interviewed had such a room available for the guests to stay in if they didn't want to stay or could no longer stay in their own guestrooms. Free food (and sometimes free entertainment) was also affered in all 
these facilities, which is, of course, the minimum a hotel can offer its guests in case of an emergency. Only two hotels refused to house people in their facility during a hurricane!

Now that all the questions and their answers have been discussed, an analysis of the hypothesis will be given in relation to the results.

\section{B. The Hypothesis}

The hypothesis in this study stated that hotel managers in hotels on Miami Beach know the dangers of a hurricane but do not spend enough time to prepare a hurricane emergency plan. In a sense, this hypothesis is made up of two parts. The first part is the claim that hotel managers know the dangers of a hurricane. This part of the hypothesis could be rejected in light of this study, for the simple reason that most managers or other respondents responsible for the administration of a hurricane plan have never experienced a major hurricane. Therefore they do not and cannot know what the consequences are of such a storm. Only $33 \%$ of the respondents lived through a major hurricane, and they are now prepared for it because they all developed some kind of emergency plan in order to decrease future losses.

The second part of the hypothesis states that hotel managers do not spend enough time to prepare a hurricane emergency plan, in other words, their plans are not elaborate enough 
to protect the hotel in an effective manner. This part of the hypothesis is supported. On 1 y $40 \%$ of the hotels have a written hurricane plan, and more than half of this $40 \%^{\circ}$ has a plan that would not be considered sufficient or effective in case a hurricane actually would hit. One sheet of paper with instructions is not enough to protect a large hotel from a natural disaster. Al1 routine as well as predictable actions or decisions should be defined in the plan. Each department needs to write its own emergency plan, after which they should submit this plan to the Security Department for review and recommendations and then pass it to management for approval. Plans should be written in a clear and logical manner, and each employee should know what his or her duties are when a hurricane hits. (See also recommendations in letter of American Red Cross, Appendix I).

Guest safety is number one, and if a hotel does not provide this safety in a reasonable manner, guests will not come back, the hotel will get a bad image in the community, or it will get in trouble with the law.

Most hotels on Miami Beach still have a long way to go in terms of hurricane preparations. Some of them just close down completely out of fair for the hurricane season! 
C. Summary of Results

A summary of the results of the questionnaires is displayed on 60 and 61 . Because al1 percentages and other answers can be seen clearly next to and in relation to each other, a better idea can be formed of the overall results.

The answers to the additional questions asked during the personal interviews are shown on page 61 .

Although some percentages were higher than expected, most answers are rather discouraging. 
QUESTIONNAIRE

In an effort to find out how well the hotels on Miami Beach are prepared for a hurricane the following questionnaire has been developed. As a manager who is perhaps most knowledgeable about the existing plans and operations of the property, you are invited to respond to this questionnaire, thereby making a valuable contribution to the future development of the quality of hurricane emergency plans in the hotel industry.

1. How many rooms does your hotel have? $157-1224$

2. When was the hotel built? $1938-1962$

3. What is your job title? Gm, Dir. of Security, Comptroller

4. How long have you been working here? 3 months -27 years

5. Have you ever experienced a major hurricane? Yes $33 \%$ No $67 \%$ When and where? Orlando '60, Daytona Brh '72, Pacific Was damage serious? Yes $40 \%$ No $20 \%$ Moderate $40 \%$

6. What are your responsibilities when a hurricane is approaching? coordinate, supervise, monitor, advise, implement plans

7. Did you assign "key personnel" to stand by in case of a hurricane? Yes $86 \%$ No $7 \%$ Voluntarily $7 \%$

8. Do you have a list with names, addresses and phonenumbers of "key personnel"? Yes $100 \%$ No__

9. Is the hotel insured in order to minimize losses when a hurricane strikes? Yes $100 \%$ No -

10. Does the hotel have provisions for emergency lighting and electricity? Yes $73 \%$ No $27 \%$

11. Do you have maps of your hotel facility readily available? Yes $67 \%$ No $33 \%$

12. Is there a list of all the records that should be protected in case of a hurricane? Yes $71 \%$ No $29 \%$

13. Do you know where to go for additional manpower, equipment and supplies when needed? Yes $100 \%$ No__ _manual" $20 \%$, special 20 .

14. What kind of warning system does the hotel have? fike $33 \%$, nothing 27

15. Do you have written safety measures to protect the guests in case of a hurricane? Yes $50 \%$ No $50 \%$

16. Are people allowed to check into the hotel after a hurricane warning has been issued? Yes $57 \%$ No $43 \%$ 
17. Would you advise your guests to evacuate in case there is a warning given out by authorities? Yes $60 \%$ No $40 \%$

18. Would you leave the hotel yourself? Yes__ No $72 \%$ Depends $28 \%$

19. Are you aware of the evacuation plans given out by the Dade County Office of Emergency Management? Yes $86 \%$ No $14 \%$

20. Did your hotel receive instructions from this Office?

Yes $40 \%$ No $50 \%$ I don't know $10 \%$

If "yes", did you act upon these instructions?

Yes $80 \%$ Part1y_ No $20 \%$

21. Does your hotel have a written emergency plan for all departments in case of a hurricane? Yes $40 \%$ Nob $6 \%$

If "yes", do all key employees know this plan?

Yes 100\% No___ I don't know

22. According to you, does your hotel comply with the South F1orida "hurricane" building code?

Yes $93 \%$ No___ I don't know $17 \%$

23. Do you have the hotel checked for deficiencies in construction etc. at least once a year? Yes $87 \%$ No $13 \%$

Questions asked during interview

Do you ever test the plan?

Do you keep the plan updated?

Do you have security protection?

Is anyone trained in first aid?

Do you have a "safe" room for the guests to stay in during a hurricane (i.e. refugee center)? $\underline{\text { Yes }}$

$80 \%$

$46 \%$

$60 \%$

$60 \%$
$\underline{\mathrm{No}}$ $100 \%$ $20 \%$ $54 \%$ $40 \%$ $40 \%$ 
CHAPTER IV

SUMMARY, CONCLUSIONS, AND RECOMMENDATIONS 
CHAPTER IV

SUMMARY, CONCLUSIONS, AND RECOMMENDATIONS

\section{A. Summary}

During the research, in which several large hotels on Miami Beach were interviewed, it was felt that the majority of the respondents were over-confident in answering the questions pertaining to their hotel. They all seemed to think that their hotel was the best ever built and that nothing could destroy it. Although most hotels did have the basic emergency equipment available, such as secondary 1 ight and power sources, maps, insurance, and small supplies (candles, batteries, etc.), they had not coordinated all these things into a well-written plan. Most managers did not deem such a plan necessary because they were convinced that a hurricane would never hit Miami Beach, and if it would, nothing could be done about it anyway. Of course, there were also some properties that were continuously working on a better hurricane plan. In general, the hotels that belonged to a large hotel corporation or a chain were the ones that were best prepared for the hurricane season. The other hotels, the privately-owned ones, will most probably never adopt any of the latest safety procedures in the hospitality industry 
B. Conclusions

Miami Beach is an area with a large number of hotels. It has long been the bait which caught the attention of investors and visitors world-wide because there the land gets the full warming effects of the Gulf Stream before it turns eastward across the Atlantic. Miami Beach in the 1960's typified the urban growth that was occurring in many areas in Florida. However, investors and constructors did not realize how dangerous it was to build hotels right on the sandy beaches. Even the 1926 hurricane did not stop them from building. In fact, it was after this hurricane that the big boom-time began on Miami Beach! Presently, in the year 1984, there are 303 hotels on the Beach with a total of 27,583 rooms. Add the thousands of residents to this number and you get a tremendous potential target area for a hurricane to make landfall.

The hazardous potential of a hurricane is often overlooked by management representatives in hotels because this area usually does not manifest itself as an operational problem encountered during the regular business day. It is probably because of this that many hotels give little or no though to planning for a hurricane. A plan will not guarantee that a disaster will not develop. However, actions taken to cope with an emergency situation may prevent a disaster from developing into a tragedy. A disaster plan should provide the basis for orderly actions and decisions so that loss can be minimized. 
Based on the results of this study it can be concluded that the majority of hotels on Miami Beach are not as well prepared as they should be, taking into consideration their location, the age of the hotels, and the legal aspects of today's fast-growing hospitality industry.

\section{Recommendations}

The following is a short discussion of the things that existing hotels and hotels-to-be could do in the event of a hurricane.

First of all, management of the hotel should get familiar with the hurricane situation in their area. They should make arrangements with the Weather Bureau or with the Office of Emergency Management in Dade County before the hurricane season so that there is sufficient time to make all preparations for safeguarding or their lives and property. After getting the proper information from these organizations, an emergency plan should be designed for the hotel, describing all duties and responsibilities in case of a major storm Other things that should be thought about are insurance, warning systems, protective works, etc. The hotel should also have reliable employees and equipment They should all know the emergency plan because they are the key to disaster management. The plan has no value at a1l unless the employees are continuously informed as to its workings. Simulated exercises should be had. The hotel should not allow any guests to check in during a hurricane warning unless the buil- 
ding is completely safe. No alcohol should be allowed on the premises to avoid tension. Only key personnel should stay in the hotel when a hurricane nears, and they should be forced to leave in case of life danger. Last but not least, the hotel should be checked for deficiencies is construction each year, and survival requirements should be made.

As far as some of the old hotels on Miami Beach are concerned, they should evacuate the beach immediately after a hurricane warning is issued. It is better to spend a few days in a refugee center on the mainland than to try and save the hotel in most cases! The majority of the hotels had no adequate hurricane plans and no security measures. This makes them even more vulnerable to a natural disaster. 
$\underline{\text { APPENDIX A }}$

HURRICANE REFUGE CAPACITIES 
HURRICANE REFUGE CAPACITIES

\begin{tabular}{|c|c|c|c|}
\hline NUMBER & REFUGE & ADDRESS & CAPACITY \\
\hline $\begin{array}{l}1 \\
2 a \\
2 b \\
2 c \\
2 d \\
03 \\
4 a \\
4 b \\
5 a \\
5 b \\
5 c \\
6 a \\
6 b \\
07 \\
08 \\
09 \\
10 \\
11 \\
12 \\
13 \\
14 \\
15 \\
16 \\
17 \\
18 \\
19 a \\
19 b \\
20 \\
21 a \\
21 b \\
22 a \\
22 b \\
23 \\
24 a \\
24 b \\
25 a \\
25 b\end{array}$ & $\begin{array}{l}\text { Miami Killian High School } \\
\text { Lorah Park Elementary School } \\
\text { Miami Jackson High School } \\
\text { Citrus Grove Junior High School } \\
\text { Kelsey Pharr Elementary School } \\
\text { Allapattah Junior High School } \\
\text { Brentwood Elementary School } \\
\text { Skyway Elementary School } \\
\text { American Senior High School } \\
\text { Lake Steven Junior High } \\
\text { Hialeah Junior High School } \\
\text { North Miami Junior High } \\
\text { Palm Springs North Elementary } \\
\text { North Miami Beach High School } \\
\text { Miami Carol City High School } \\
\text { South Dade Senior High School } \\
\text { Norwood Elementary School } \\
\text { Shenandoah Elementary School } \\
\text { Miami Edison High School } \\
\text { Flagami Elementary School } \\
\text { Lindsey Hopkins Tech. ED. } \\
\text { Southwood Junior High School } \\
\text { Kendall Lakes Elementary School } \\
\text { McMillian Junior High School } \\
\text { Highland Oaks Junior High School } \\
\text { Royal Green Elementary School } \\
\text { WR Thomas Junior High Shool } \\
\text { Miami Southridge High School } \\
\text { North Miami Senior High School } \\
\text { Pine Lake Elementary } \\
\text { Miami Sunset High School } \\
\text { Gloria Floyd Elementary } \\
\text { Miami Coral Park High School } \\
\text { Miami Springs High School } \\
\text { Amelia Earhart Elementary School } \\
\text { Hialeah-Miami Lakes High School } \\
\text { Miami Lakes Junior High School }\end{array}$ & 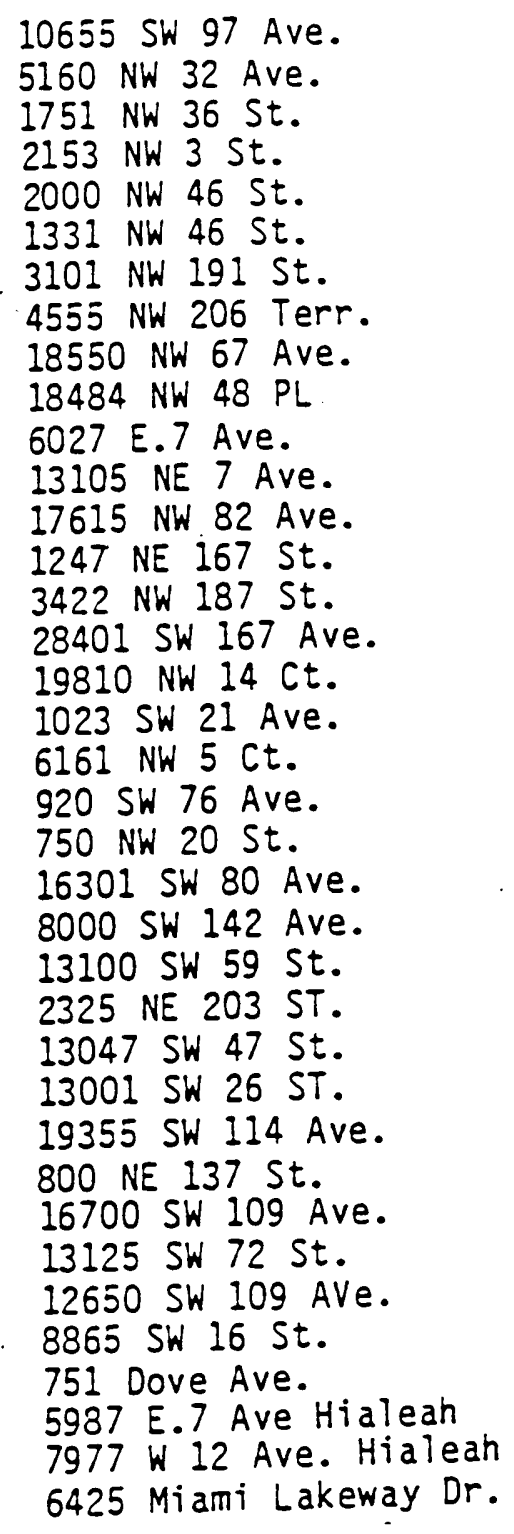 & $\begin{array}{l}2,000 \\
800 \\
1,200 \\
800 \\
550 \\
525 \\
1,000 \\
525 \\
2000 \\
800 \\
1,000 \\
420 \\
525 \\
2,000 \\
1800 \\
1400 \\
500 \\
680 \\
1,000 \\
600 \\
2,500 \\
800 \\
1,000 \\
800 \\
800 \\
1,000 \\
800 \\
2,000 \\
2,000 \\
1,000 \\
2,000 \\
800 \\
2,000 \\
900 \\
1,000 \\
2,000 \\
1,500\end{array}$ \\
\hline
\end{tabular}


APPENDIX B

DADE COUNTY TRAFFIC-EVACUATION ZONAL DATA 
DADE COUNTY TRAFFIC-EVACUATION ZOMAL DATA

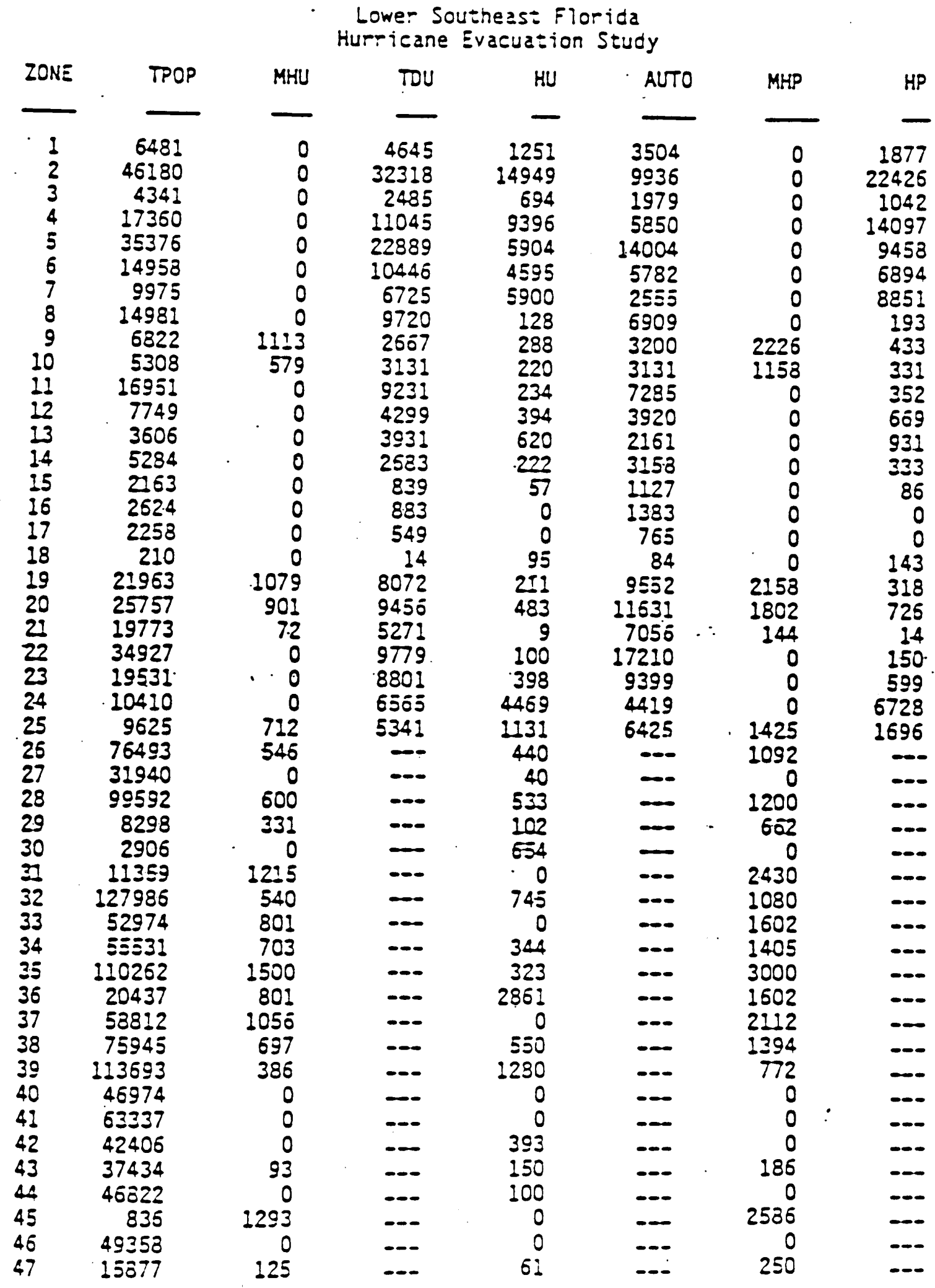

TPOP = TOtal Pooulation

MHU = of Mobile Home Units

AUTO = \# Of Residential Vehicies TOU = \# of Total Dwelling Units

MHP = MoDile Home Population

HP = Hotel/Motel Population 
APPENDIX C

DADE COUNTY ASSUMED EVACUEE

PERCENTAGES BY DESTINATION TYPE 
APPENDIX C

$$
\begin{aligned}
& \text { DADE COUNTY ASSUMED EVACUEE } \\
& \text { PERCENTAGES BY DESTINATION TYPE }
\end{aligned}
$$

CATEGORY 1-3 STORM CATEGORY 4 4-5 STORM

HIGH LOW HIGH LOW

PARTICIPATION PARTICIPATION PARTICIPATION PARTICIPATION

RED CROSS

REFUGES

$20 \%$

$15 \%$

$25 \%$

$20 \%$

FRIENDS*

65

45

60

50

HOTEL/MOTEL *

15

10

15

12

NOT EVACUATING

$\underline{0}$

$100 \%$
30

$100 \%$ $\underline{0}$

$100 \%$
18 $100 \%$

* Of those going to the home of a friend or hotel/motel units it is assumed approximately $63 \%$ would stay in Dade County, 9\% to Broward, $3 \%$ to Palm Beach County and $25 \%$ would go out of the region. 
APPENDIX D

SAMPLE INTRODUCTORY LETTER 
Gina Brink

$4805 \mathrm{NW} 7 \mathrm{th}$ Street \#305

Miami, FL 33126

October 11,1984

I am a graduate student at Florida International University and $I$ am presently doing a study on hurricane preparedness of hotels on Miami Beach. I would hereby like to ask you for some assistance - all I ask is a few minutes of your time.

As you might know, hurricanes can be very dangerous and devastating, especially as they approach the mainland. A seafront hotel, such as yours, needs to be prepared for such a disaster. Some hotels have developed a written "emergency preparedness plan" in order to deal with an upcoming hurricane. What I would like to ask you is to assist me in determining how well the hotels on Miami Beach are prepared for a hurricane. I have enclosed a questionnaire which I would like you to fill out and which will take no more than ten minutes of your time to answer.

Safety in the hospitality industry is a big issue nowadays. I am sure you will be willing to cooperate with me in trying to improve this safety.

I will get in contact with you in about two weeks in order to pick up the questionnaire, with your permission. Thank you for the courtesy of your assistance.

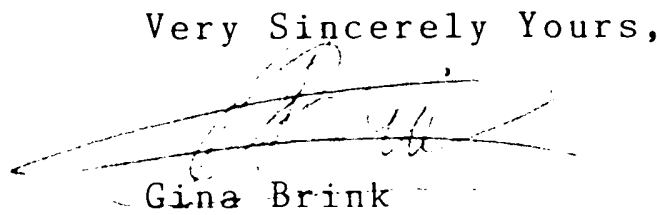

Enclosed: Questionnaire 
APPENDIX E

SAMPLE QUESTIONNAIRE 


\section{QUESTIONNAIRE}

In an effort to find out how well the hotels on Miami Beach are prepared for a hurricane the following questionnaire has been developed. As a manager who is perhaps most knowledgeable about the existing plans and operations of the property, you are invited to respond to this questionnaire, thereby making a valuable contribution to the future development of the quality of hurricane emergency plans in the hotel industry.

1. How many rooms does your hotel have?

2. When was the hotel built?

3. What is your job title?

4. How long have you been working here?

5. Have you ever experienced a major hurricane? Yes No When and where?

Was damage serious? Yes___ No

Moderate

6. What are your responsibilities when a hurricane is approaching?

7. Did you assign "key personnel" to stand by in case of a hurricane? Yes__ No

8. Do you have a 1 ist with names, addresses and phonenumbers of "key personnel"? Yes__ No

9. Is the hotel insured in order to minimize losses when a hurricane strikes? Yes__ No

10. Does the hotel have provisions for emergency 1 ighting and electricity? Yes_ No

11. Do you have maps of your hotel facility readily available? Yes_ No

12. Is there a 1 ist of all the records that should be protected in case of a hurricane? Yes_ No

13. Do you know where to go for additional manpower, equipment and supplies when needed? Yes__ No

14. What kind of warning system does the hotel have?

15. Do you have written safety measures to protect the guests in case of a hurricane? Yes__ No

16. Are people allowed to check into the hotel after a hurricane warning has been issued? Yes__ No 
17. Would you advise your guests to evacuate in case there is a warning given out by authorities? Yes $\mathrm{No}$

18. Would you leave the hotel yourself? Yes No

19. Are you aware of the evacuation plans given out by the Dade County Office of Emergency Management? Yes No

20. Did your hotel receive instructions from this Office?

Yes No I don't know If "yes", did you act upon these instructions? Yes Partly No

21. Does your hotel have a written emergency plan for all departments in case of a hurricane? Yes No If "yes", do al1 key employees know this plan? Yes No I don't know

22. According to you, does your hotel comply with the South Florida "hurricane" building code?

Yes No I don't know

23. Do you have the hotel checked for deficiencies in construction etc. at least once a year? Yes No 
APPENDIX F

TABLE OF CONTENTS OF A

HURRICANE PREPAREDNESS PLAN 


\section{APPENDIX F}

SAMPLE TABLE OF CONTENTS

FOR A HURRICANE PREPAREDNESS PLAN

I. Introduction

II. Emergency phonenumbers for municipal services

III. Departmental team responsibilities

a. Command center

b. Engineering

c. Food and Beverage

d. Kitchen

e. Housekeeping

f. Pool, Tennis

g. Front door team

h. Security department

i. Other departmental responsibilites

IV. Standard letter of warning to guests

V. Hurricane tracking map

VI. Definitions of weather terminology

VII. Approved hurricane refuge areas

VIII. Equipment for hurricane season and power failure

IX. Letter of elevator maintenance

X. Contract from window washing contractor

XI. Private lines of department heads in case of an emergency or power failure

XII. Cônfidential staff home phone numbers

XIII. List of elevator phone numbers and their locations XIV. Updated C.P.R. Iist 
$\underline{\text { APPENDIX G }}$

EXAMPLE OF A SIMPLE HURRICANE PREPAREDNESS PLAN 


\section{FLOODING}

1- BOARD UP ALL ENTTRANCES WTTH THE ADUUSTABLE BOARDS AND SAND-BAGS.

2- ELEVATORS TO BE ADJUSTED NOT TO GO TO LOWER LOBBY.

3- TURN OFF BOILERS

4- TURN ON CASOLINE PUMP IN BOILER ROOM.

HURRICANE

ALL THE ABOVE PLUS THE FOLIOWING:

1- BOARD UP WINDOWS IN FRONT OF THE COFFEE SHOP AND PATIO BAR.

2- REMOVE ALL CHAIRS AND CHAISE LOUNGES FROM POOL AREA

3- BOARD UP ALL OCEANFRONT EAST CABANA DOORS.

4- BLOCK OFF PEACOCK ALLEY.

5- LOCK DOOR TO POOL ENTRANCE OFF MAIN LOBBY.

6- LOCK OCEANERONT DOOR ON THE EAST END OF RICHELIEU ROOM.

7- TIE DOWN MAIN CHANDELIER IN RICHELIEU ROOM.

8- MAKE PREPARATIONS FOR "KEY PERSONNEL" TO STAY OVER IN HOTEL.

9- EXTRA SAND-BAGS TO BE FIILED AND USED WHERE NEEDED.

10- PLACE HURRICANE SHUTTERS OVER MARQUEE.

11- HAVE AMPLE SUPPLY OF CANDLES AND FLASHLIGHTS AND BATTERIES. 
$\underline{\text { APPENDIX H }}$

THREE EXAMPLES OF AN EXTENSIVE

HURRICANE PREPAREDNESS PLAN 


\section{APPENDIX H-1 \\ HURRICANE/TYPHOON}

The hurricane/typhoon season starts in June, but an emergency organization should be formed by May to make plans in advance for violent weather. The team should be aware of the immense destruction that such tropical storms can produce and the need for acting together quickly should one threaten to strike. (In the remainder of this article, all references to emergency procedures for a hurricane apply equally to typhoons.)

Before the hurricane season starts, the team should have on hand at the inn the following equipment:

-A supply of containers suitable for drinking water (allow

$\frac{1}{2}$ gallon per day per person for three days).

-A battery-operated radio with spare battery.

-Flashlights with spare batteries.

-Storm shutters or plywood for covering plate glass windows on ground floors.

-Burlap bags suitable for sandbagging (burlap will stretch and not tear as it absorbs water).

-Rope for lashing down storage sheds, patio furniture, etc.

-Fully stocked first-aid kits.

To avoid last minute confusion, check continually to see that dead limbs, coconuts, and other debris are removed from the trees and grounds. Check emergency generators and sump pumps regularly. Review and practice "board-up" procedures so that they can be executed quickly and efficiently when the need arises. Clear and check roof drains and surfaces regularly. Check window and door locks regularly.

Hurricane Watch

A hurricane watch is issued when a storm threatens to hit the area within 24 to 36 hours. When the weather bureau issues a hurricane watch, the emergency organization should move smoothly into action. Each department head should take the preliminary action outlined below so all departments are ready if the storm continues on the established course. 
Division of Responsibility

Irrikeeper:

- Monitor radio and television broadcasts for storm information.

-Keep department heads posted on storm progress.

-Monitor the progress of préparations within the inn.

-Inform guests through the front desk of the storm's progress and the precautions being taken by the staff.

-Determine how many employees will be available to work during the storm.

Engineer:

-Fill hotel vehicle with fuel and park in a high, protected area.

-install storm shutters or plywood over low level windows.

-Move tools (hammers, saws, nails, axes, crowbars, etc.) that may be useful during or after the storm to a safe place.

-Begin filling sandbags for later use in the critical areas.

Housekeeper:

-Remove furniture from all low level rooms and place it in upper floor storage rooms or meeting rooms.

-Relocate pool furniture, outside trash cans, etc. to low level rooms that have been emptied of furniture. Secure these rooms.

-Outside furniture, equipment, or storage sheds that cannot be relocated. should be securely lashed in place.

-Check to see that nothing is stored in electrical rooms, mechanical equipment rooms or sump pump rooms.

Food and Beverage Director:

- Move at least a three day supply of canned goods and other non-perishable items to an upper floor room.

- Relocate candles, cooking utensils and sterno to a room near the food items. 
-Purchase and store with the food a three-day supply of paper plates, plastic flatware, and trash bios.

- Clean and sterilize the drinking water containers.

-Remove all goods from pool bars.

Front Desk Manager:

-Contact each guest and explain the storm's status and the emergency preparations of the inn. Allow the guest to decide if he/she should leave.

-Relocate guests on lower floors to upper level rooms.

-Relocate essential accounting records, monies, office machines, etc., to an upper level room.

\section{Hurricane Warning}

A hurricane warning means that a storm is expected to hit a specified area within 24 hours.

Begin final preparation for the protection of life and property immediately. Know where the eye of the hurricane will strike the coast and know its velocity. These facts are crucial to yoür-emergeñcy preparations. In the northern hemisphere, winds move in counter-clockwise rotation. This can cause severe flooding and wind damage if the eye hits within 20 miles to the south of your location. If the eye passes directly over you or to the north, the flooding will be minimal, but the winds will still be high. Use this information to be prepared for both situations.

Division of Responsibility

Innkeeper:

-Notify the guests and staff that the hurricane will hit soon.

-Continue to follow the storm's progress by monitoring the radio.

-Have employees who wish to work at the inn during the storm move with their families into the inn.

-Coordinate the activities of the department heads making preparation for the storm. 
Engineer:

-Check emergency generator, emergency lights, tools, and supplies.

-Disconnect power to all low-lying portions of the inn.

-Secure all rooftop and lower level doors

-Begin sandbagging areas that are subject to flooding.

Housekeeper:

-Move as many towels, laundry supplies, etc., as storage space allows to an upper floor.

-Fill all tubs and sinks with water for drinking, washing, and sanitation.

-Have your staff ready to aid other departments if needed.

Food and Beverage Director:

-Fill water containers and store them with canned foods.

-Turn freezers and refrigerators to their coldest settings.

Do not open these unless absolutely necessary.

-Move stored goods to the highest shelves away from possible flood waters.

Front Desk Manoger:

-Help the relocated guests settle into their new rooms.

-Plan activities to keep the guests entertained.

-Make available to guests and staff the latest storm information.

During the Storm

-No one is to leave the building unless it is an extreme emergency.

-Sandbag at the entrance of the water, then evacuate to a higher floor, if necessary.

-Watch for flooding conditions in the hotel. Continue to use public utilities until they fail. 
-Open the leeward (facing the direction in which the wind is blowingl windows to release the pressure.

-If the eye of the hurricane passes directly overhead, do not go outside; the winds start up again rapidly. Be prepared for this by closing the opened windows, and opening the windows on the opposite side of the building. The wind direction will switch after the eye passes.

- Consumption of alcoholic beverages by staff or guests during the storm is prohibited.

After the Storm

-Survey the damages and report to the district office and the Loss Prevention Department by the most expedient means of communication.

-Instruct the engineer to make temporary repairs that will limit losses from the heavy rain that follows a passing storm.

-Coordinate through the district office the cleaning, checking, and repairing of electrical and hydraulic equipment.

-If heavy damage is incurred notify the district office, the Loss Prevention Department, and the GAB.

-Submit a Loss and Incident Report containing all pertinent information about the damage. 
Relocate guests from lower floors to upper floors.

-Move essential accounting records, cash, office machines, etc. , to upper floors, if required.

-Make sure that the latest weather information is available to guests.

Guests and Employees:

-Avoid areas subject to sudden flooding.

-Do not attempt to cross water that is deeper than the level of your knees.

-Do not attempt to drive over flooded roads.

\section{After the Flood Waters Recede}

-Dispose of fresh food that has come in contact with flood water.

-Have drinking water tested for possible contamination.

-Do not handle live electrical equipment in wet areas. Check and clean electrical equipment before returning it to service.

-Use flashlights, not lanterns or torches, to examine flooded sections where flammable gases may be trapped.

-Report broken utility lines to the appropriate authorities

-Start clean-up and salvage operations.

-Maintain communications with the district office, the Loss Prevention Department, and GAB. 
The following are to serve as officers:

GENERAL CO-ORDINATOR:

ASSISTANTS TO GENERAL CO-ORDINATOR:

CHIEF OF COMMUNICATIONS:

Area Co-Ordinators:

CABANA CLUB:

REAR PLATFORM:

FRONT DOOR PARKING AREA AND RAMP:

HOTEL PROPER--GROUND FLOOR AREA:

HOTEL UPPER FLOORS:

ALL KITCHEN AND RESTAURANT AREAS:
Executive Manager

Security Director

Telephone Supervisor
Manager

Security Person/Purchasing Manager

Front Office Manager

Convention Co-Ordinator

Housekeeper

Executive Chef and Food \& Beverage Director

You are requested to submit to $\mathrm{Mr}$.

the names, addresses and telephone numbers of those who wish to assist in the event of such an emergency. It is imperative that you furnish such names to this office within the next few days. Telephone numbers should be recorded with each TOP CO-ORDINATOR and copies of same are to be furnished to the GENERAL CO-ORDINATOR and CHIEF OF COMMUNICATIONS so that no time is lost in assembling the necessary staff who should be instructed to report at once to their assigned duties. If you are not at home or have left for a safer place, please give the address and telephone number to the General Co-Ordinator and Chief of Communications as well.

For complete coverage there are to be four (4) TOP CO-ORDINATORS assigned to and responsible for the following sections to the GENERAL CO-ORDINATOR:

1. CABANA ClUB:

2. FRONT DOOR, PARKING AREA AND RAMP:

3. HOTEL (PROPER) GROUND FLOOR AREA:

4. HOTEL FLOORS:
Manager

Security Person and Head Doorman

Convention Co-Ordinator

Executive Housekeeper

To each of the above four groups the GENERAL CO-ORDINATOR will assign one assistant and give to each, a crew sufficient in number to perform the following duties.

1. SECURE THE CABANA CLUB

2. SECURE THE FRONT DOOR, PARKING AREA AND RAMP

3. SECURE THE HOTEL GROUND FLOOR

4. SECURE THE HOTEL UPPER FLOORS INCLUDING ROOFS 
The Chief Engineer will require four (4) crews of three (3) men on storm shutters, under the direction of his assistant as Top Co-Ordinator. This group is to stand ready for any emergency which may arise within the area for which they are responsible. In addition to the above, the Chief Engineer will need an additional number of men divided into groups for light and other emergency purposes. Each one of these key men will be responsible for one floor of the building in making the necessary preliminary precautions, after which they will stand ready for reassignment wherever needed.

The Chief Engineer is responsible for providing hall, stair and exit lights. It will be the duty of his men to place portable lights in halls and exits.

PRE-HURRICANE GENERAL INSTRUCTIONS

Remove all furniture not necesary to the operation from outdoor areas and store as directed.

The Chief Engineer should see that an ample supply of tools and materials has been purchased in advance and placed at a distribution center where all top co-ordinators may requisition same.

SUPPLIES

SANDBAG'S - 12 DOZEN FILLED

MASKING TAPE - 24 2" ROLLS

ROPE, SAWS, PLIERS, SCREWDRIVERS

PORTABLE LIGHTS

CANDLES $\mathbb{N}$ HOLDERS

FLASHLIGHTS AND BATTERIES (MINIMUM OF 12)

SQUEEGEES

\section{INVENTORY}

AS OF JUNE ' 84
NEEDED

BOTTLED WATER

1ST AID KITS

DRY ICE

GAMES FOR ENTERTAIN

Store furniture away from windows, doors and passageways. Shutter the Porch, main lobby, card room and mezzanine windows. Order the lighting of the candle jars on stair wells, landings and wherever else they are located in case of power failure.

\section{POINTS WORTH REMEMBERING}

1. Procure tools and material for protection well in advance.

2. Order supply of dry ice for regrigeration of supplies in case of 'no emergency generator'. KEEP THIS ICE WRAPPED UNTIL POWER FAILURE at each place where it is to be used. Consult with food purchasing department on this.

3. With present day methods of weather detection, much attention should be given to the duration of the storm. If it is of long duration, three hours or longer, and before power goes of $f$, communications department is to contact all guests and department heads to fill bath tubs with water to be used for toilets - water in faucets for drinking only. The kitchens are to fill all sinks, pots, milk cans and tubs with water. The night club and bars will do likewise. 
4. In case of power failure, secureamonia and air conditionine machinery, oil burners, and other equipment operated by puwer.

5. Provide in advance, emergency lights for public halls, rooms and offices. In the absence of an emergency generator, use candles in glass jars filled 1/3rd with sand on stairwells. (Engineering Department)

6. Above all, it is the duty of the security department to provide round-the-clock protection for the entire property before, during and after the storm and until such time as conditions become normal again. It is also the duty of our Chief Security officer to marshall a sufficient number of his first aid's men to stand by for any emergency that may arise.

7. If all those participating in this program will perform their assigned duties with confidence and assurance, our guests and visitors will feel more secure.

8. The General Co-Ordinator is in full command. You are at his beck and call until he has officially released you through your co-ordinator or key man. All crew assignments should be covered by an alternate in case the regular assignee is unable to report due to illness, etc.

In the absence of a co-ordinating meeting, each top co-ordinator is expected to prepare written instructions for each single or group assignment so that valuable time may be saved for any emergency which may arise. Submit these instructions to Mr. for coordination of effort before issuing same.

In the event of a hurricane warning, the Chief Engineer will remain by his telephone in his office.

\section{SCHEDULE FOR CABANA CLUB}

In this area, a crew of men will be divided into three (3) groups to function as follows: The oceanfront group is to be comprised of two (2) assistant co-ordinators and a sufficient number of crew men.

The pool deck is to be comprised of one (1) asisstant co-ordinator, a senior life guard and crew men.

The cabana club and rest rooms are to be comprised of two (2) assistant co-ordinators and necessary crew members.

Tools with which to work such as knives, screwdrivers, hammers, nails, masking tape and rope should be passed out where necessary and should be returned to storage when through.

Crews will then be divided into above mentioned groups and given proper instructions. They will proceed as follows:

The oceanfront group must bear in mind that all furnishings and furniture are to be moved to the first floor west cabana area and secured in cabanas which have doors that are closed and blockbraced. The oceanfront group must begin storing all beach furniture in the cabanas as well. All signs, water coolers, table, trash cans, mats and protable bars are to be secured behind closed and locked doors. Anything that the wind can pick-up, upset, or pitch and toss must be secured. cabana doors are to be braced. 
Pool Deck -- Drop pool approximately $\frac{1}{4}$. All chaisettes, awnings, mats, covers, chairs and other furniture along with pool stanchions, ropes, canvas tops and anything which might pitch and toss with the wind must be secured behind closed, locked and braced cabana doors.

Ocean Lounge -- Remove all tables, chairs, trash cans, desks and signs and take into the Porch and secure same properly. This group will then make certain that all doors to rest rooms and locker rooms are properly secured and sandbagged. Nothing is to be left on the floor where there may be a chance of water ruining it.

The cabana office equipment is then made secure, making certain that no records are subjected to any hazard.

All signs, trash cans, chairs and any other movable object is to be moved out of the cabana area.

\section{SOLARIUM}

Remove all furniture, tape allwindows, turn off all equipment and remove all pertinent papers and records.

\section{FRONT DOOR PARKING AREA}

This group is to be headed by a top co-ordinator, one assistant and necessary crew memebers. This group includes parking concessionnaire manager and staff. All cars must be removed from the lot due to possible flooding. This is the responsibility of the car owners.

Signs, trash cans and office equipment are to be moved, doors shuttered or reinforced, awnings (if any) and unbrellas taken down and secured. Any light potted plants will be moved out of the way of the wind. All records and keys, still outstanding, will be moved within the safety area as designated by the top co-ordinator.

All cars parked on the lot or against our building will be properly braked and windows rolled up. The parking area, ramp, rear platform and garbage room will be secured. All loose debris or equipment is to be secured properly and all doors, entrances, or windows closed, and if necessary, barricaded or shuttered.

All of the above personnel are to remain at the front entrance to assist any and all who may require assistance until such time as it becomes dangerous to remain at which time they will be reassigned.

\section{SUPPLEMENTARY HURRICANE SUGGESTIONS -- ENTERTAINMENT}

In our first Hurricane Advisory Guide, you no doubt noted that nothing was said about the care of our guests during storm emergencies. This was done on purpose. To get our property bedded down is of first importance because in so doing, we will have achieved the second step which is that of taking care of all those who are registered in the hotel or are merely seeking shelter from the storm. 


\section{SUPPLEMENTARY HURRICANE SUGGESTIONS -- ENTERTAINMENT}

Only registered guests of the hotel should be permitted ahove the main floor lobby level. All others may use our public rooms.

There will be an entertainment program set up for our guests co-ordinated by our convention service manager.

Ample hurricane lanterns and candle lights should be used to be able to have public rooms operate as efficiently as possible.

RULE NUMBER ONE FOR ALL OF US -- walk fast but never run -- running causes stampedes.

RULE NUMBER TWO FOR ALL OF US -- speak with a calm voice at all times during storm emergencies - it restores confidence.

Ask people to stay away and keep people away from windows and doors. Don't permit anyone to block hallways entrances and exits.

\section{GUEST INEORMATION ON ANNOUNCEMENT OF HURRICANE}

1. FILL BATH TUBS WITH WATER

2. STAY AWAY FROM WINDOWS

3. GUESTS WILL TAKE MATRESSES, BLANKETS AND PILIOWS AND USE HALLWAYS

4. FOOD WILL BE AVAILABLE IN THE MONA LISA ROOM

Evacuation procedures are co-ordinated by the Civil Defense and American Red Cross. Their suggstions and shelter locations will be forwarded to every department head within the next few days. 
1. inemo to Management and Security Managers of position, wind speed, direction, travel speed, name. Also include qualified estimate, "If hurricane continues at current course and speed, could hit our area in approximate number of hours----date----time----.

a) Memo to Hotel Managers and Personnel, Purchasing Agent, Chief Engineers.

b) Personnel Director to have Department Heads update home phone numbers and establish number and names of employees to work during hurricane.

c) Engineering to advise Management of needs.

Note: Engineering should now prepare for future hurricanes and stock sandbags, plywocd, raingear, and other items that can readily be stored for future use)

d) Security Manager's check with U.S. Weather Bureau for iheir predictions and keep Hotel Management updated.

e) Security inventory first aid supplies and equipment and prepare basic emergency kits

f) Suggest Hotel Management have meeting with all Department Heads to discuss preparations, establish labor pools and provide for future meetings as hurricane approaches

g) Security to be ready fo establish communication center and insure good portable Nadio is available

h) Management memos to be sent out re: emergency generators and condition, pumps on hand and to be rented, refrigerator trucks, food and beverage supplies to be on hand or ordered

i) Convention Sales and Reservations be prepared to alert or cancel incoming groups and guests

j) Hotel comptrollers to have adequate cash - change on hand to provide for mass checkouts...minimum amount -- to be secured in Hotel safe k) Management to decide if Hotels will accept guests -
reservations

1) Security check out fire equipment, alarms, burglar alarms 
PHASE II

HURRICANE WATCH

1. Supplementary memo to Management of hurricane status and possible time of arrival.

2. Management has another Department Head Meeting

a) equipment and supplies detailed

b) staffing needs refined

3. Goods and furnishings removed from lower storage areas to higher floors. Loose outside objects stored inside designated areas. To be done in advance while personnel on hand -- could hit over weekend or holiday, when smaller number of staff on hand

4. Staffing policies to be announced:

a) Head of household may bring immediate family who live in household

b) Non-immediate family get special rate - but not comped

c) Food \& Beverage - better accounting proceedures to be established

d) Personnel to establish labor pool and possible assignments excess number of personnel in one department can be assigned to another where needed.

5. All Security Personnel on standby and immediately available

a) Security personnel advised that all will report for duty when hurricane warning is announced (24 hours) prior to hurricane arrival

6. Security Department

Security Communications office set-up and manned 24 hours a day

a) Establish hurricane log now for current notes and future usage - to be used by each security Manager throughout the hurricane -- hurricane related activities to be logged in this separate book by security staff

b) Vehicles gassed and extra 20 gallons in can

c) Emergency first aid kits prepared 
d) Flashlights, batteries, tape, rope, sandbags, portable radios, etc. on hand (cheap AM radio each fixed post)

e) Radios ( 2 way communications) and beepers reassigned by priority - (e.g.: Grounds radios to security and returned for clean up later)

f) Rooms at Hotel assigned and list provided (to Front office Manager)

g) Each officer and investigator maintains his own patrol log in books provided to him

7. Groups and incoming guests should be specifically assigned to safest rooms in Hotels and Lodges
a) Hotels - Lower floors to west side of building
b) Lodges - No lower level floors - concentrate Lodges for maximum security protection

8. "HurricaneWarning Notices"

a) Printed now by Rod - English and Spanish (De La Vega)

b) Notices provided to Management at time deemed best by Mr. (-..-- $)$

c) Key employees and department heads to have copies for informational purposes

d) To be posted in elevators and public areas

e) Date and time issued to be entered in Hurricane Log Book by Security Managers

f) Revise and add to notice:

1. No tape on windows and why

2. Information Desk at Main entrances once Hurricane Warning announced or when TV power failure occurs.

3. Room Key \& I.D. required

g) On Beach Notice use west stairwell ONLY

h) More information on power failure in IMPORTANT NOIICE TO GUEST

9. Management to have signs printed and available for year round use stating "Elevator oui of service, use stairwell" 
PHASE III

HURRICANE WARNING

1. Management has another Department Head Meeting (are)

a) Personnel on standby is to be brought into the hotel

b) Front Desk to have rooms assigned upon employee arrival Employees advised not to bring their cars to the Hotel

c) Specific duties of each department discussed and labor pool assignments made

d) Put into effect specific departmental duties

e) Department Heads to keep a record of the times employees work as T.K. will be secured later on

f) Notice to employees in Spanish \& English personnel "NO PETS"

2. Front Desk does not accept local reservations

3. Operations Manager or designated Manager to control labor pool assignments

a) Before any department secures work force he MUST contact Operations Manager and ascertain if labor pool is needed in other areas

b) Department heads are to keep Operations Manager advised of the status and completion of assigned tasks.

4. Security to do a complete survey of the property listing areas that are not secured and all recommendations to secure areas. :This survey is to be turned over to the operations Manager for assignment and correction.

a) Security personnel to be assigned specific duties as outlined for each property

b) Once all employees have arrived, the timekeeper area will be secured. Have meeting with all Security personnel

c) Candles and all first aid supplies are to be issued and assigned to security personnel

d) Hotel operator is to be advised of assignments and where to funnel calls 
e) Arrange for food and drink for personnel assigned

f) Monitor storm and advise personnel over the radio or telephone of status on anticipated force of the hurricane

g) Set-up scheduling to return to normal operation once the danger has passed. This scheduling is tentative and will constantly need to be updated.

h) Assure that Management has issued "Hurricane Warning Notices"

i) Set up Hurricane Information Desk

j) An ample supply of sheets and towels should be on hand for use as bandages.

5. All guests in Ocean Front Rooms or floors that may flood are to be re-located to safer areas. Guests not allowed to stay in rooms during hurricane - to assigned meeting - conference rooms.

6. Guest should be encouraged to re-locate to a designated Hurricane Sherlter

a) In Hotel

b) Out of Hotel (Locations of Public Shelters)

Issue - hand out hurricane candles (?) prefer flashlights to guests

OLIN: Volume cost of cheap flashlights - small \& cheap store in Security

Issue notice and flashlight - flashlight just before storm hits

7. All vehicles and yachts to have been put in safe storage

8. Pregnant women - advised of possible medical problem relative to barometric pressure- advised to go to the hespital - six months or over

9. Security to inspect safety measures sandbags, etc. - log in book advise management if any problem 
PHASE IV

FULL IMPACT OF THE HURRICANE

1. Order remaining guests to go to and remain away from windows and glass doors.

2. Calm guests and assure them that every precaution has been taken.

3. Secure areas that damage occurrs as best as possible

4. Operations Manager is to establish work crew schedules to be put into effect once the hurricane passes

5. Note times of power failures-phone service termination

6. Guard - Secure areas exposed to theft. Example: liquor in bar money in offices

7. Emergency First aid - \& records of all first aid rendered

8. Communications - need repeater - We supply one of our hand radios to police or civil defense for extreme emergencies

PHASE V

EYE OF THE HURRICANE

1. Keep all personnel inside explaining that as the center of the hurricane or the "eye" passes over your area, this will only last from a few minutes or one-half hour, then the winds will again rise rapidly from the opposite direction. Do not be misled by calm.

2. Insure all perimeter doors still locked, so as to control access at Main Entrance

3. Check Hotel for injured people or exposed windows, etc.

4. Emergency repairs only if can be done in complete safety 
1. When the hurricane is over, do not allow guests or employees to go outside until the area can be surveyed for hazards, such as, low hanging power lines, or fallen trees on power lines, washed out areas, broken glass, etc.

2. The Operations Manager will receive a report of all damages and clean-up; needed. As soon as the conditions improve clean-up and repairs should be made as soon as possible.

3. Food operations will most likely be required by our guests, therefore, food preparation and service must be operational as soon as possible.

4. If we have experienced power failure, all refrigerated foods must be checked out and arrangements made to store food or dispose of spoiled food.

5. Resume normal functions as soon as possible

a) Contact employees and bring in crews, immediately

6. If damage is severe and hazardous to guests, have them remain inside and DO NOT let them venture outside.

7. Security to take photos before cleanup of whatever may lead to insurance claims, civil suit, major repairs, etc.

8. Insure all necessary first aid has been rendered

9. Secure rooms - protect guest valuables exposed to theft (e.g. place exposed jewelry, camera, cash, etc. in laundry bag, mark room number, date and time secured, and who secured or took items). 
APPENDIX I

AMERICAN RED CROSS:

RECOMMENDATIONS FOR HURRICANE PLANNING 
Dade County Chapter 5020 Biscayne Boulevard P.O. Box 370968 , Buena Vista Station Miami, Florida 33137

(305) $576-4600$

\section{RECOMMENDATIONS FOR HURRICANE PLANNING}

A hurricane of major proportions making a landfall in Dade County is a real possibility and South Florida is long overdue. The losses and damages will be devastating. Such a disaster is everybodys problem, not the exclusive problem of the Red Cross, County or State governments.

.... Each department (e.g. engineering, housekeeping, food and beverage, public relations, maintenance, pro-shop, etc.) needs to write a similar plan for their department

a) Department plans should be submitted to Security for review and recommendations and then passed to Management for approval.

b) Each employee, by position title, not by name, should know what is expected of him or her.

c) Department plans should be reviewd annually; preferably in June before the hurricane season.

d) Departmental plans should follow the scenario or format of the Security Department, that is, from threat, to watch, to warning, to all clear. This "time line" approach to a hurricane plan is the best outline to follow.

After management approval, the departmental plans are included in the "master plan" as an annex to the Security Department's plan.

The Director of Security should be formally named as the "Disaster Control officer" if this has not already been done. Staff would then know who to report to for direction when it is determined by management that the plan should go into operation.

.... Serious consideration needs to be given to providing shutters, either mechanical or non-mechanical, to the large glass areas in the public dining and banquet halls:

a) There are expensive furnishings, chandeliers, carpets and works of art that would be very difficult to replace when one of the windows blow out.

b) There is a great deal of contruction in the area and hurricane force winds will pick up objects from the ground, roadways, other roof tops, etc. It is the wind blown debrig that breaks glass even though building designs meet a $125 \mathrm{MPH}$ wind storm safety factor.

c) While shutters may require a fairly substantial capital outlay, there are tw possibilities management should actively pursue in terms of cost recovery:

- their depreciation for tax purposes

- a reduction in the windstorm insurance premium

The risk reduction of shuttering these public rooms would be considerable and provide a certain "peace of mind" to the corporate owners and managers. 
1. The Hotels on the Beach have major exposures to both the storm surge, whlch could be seventeen feet above normal high tide in a category five storm, and the severe winds generated by a hurricane.

2. The hotel's engineering department should ascertain the buildings lower level above mean sea level and then project the effect of various water levels in the building.

3. Again, each department at the Hotel needs to outline a plan for thelr department

4. Again, radio communications independent of FPL power needs to be installed.

5. plywood, 2X4's, hammers and nails to board up exposures after the storm, should be in supply before the hurricane season in June. Tha 6 taff should be provided with a second or third floor interior, windowless room as an emergency operation center.

6. Encouraging hotel guests to seek Red Cross shelters on the mainland is sound, but there may be some public relations problems involved.

a) Red Cross shelters will be crowded and without electric power in due course of time. That means no lights, no air conditioning and no cooking facilities in some buildings.

b) Cots and blankets will be in very short supply, about one for every ten people. Red Cross constantly tells people to bring folding cots, pillows, alr mattresses, blankets, etc. There will be dormitory style sleeping arrangements.

c) While Hotel guests would be as welcome as anyone in a Red Cross shelter, management needs to decide if they want to make such a recommendation to their hotel guests.

7. There is no way I, or anyone in the Fire Rescue Service in Miami Beach, would encourage or recommend that hotel guests remain in the hotel during a hurricane.

8. We discussed a hold harmless statement that guests would sign if they wanted to stay, but this could create difficult legal problems. For example, when the governor or mayor issues an evacuation order in the interest of public safety and the hotel permits guests to remain on its premisis, this could later be construed as the hotel Corporation defying the public safety proclamation.

\section{Guest safety}

a) Guest safety is the primary reason to take hurricane precautions and develop a plan of action.

b) Public relations encompasses both the guest's treatment and how the local community visualizes the corporation.

c) Extending an invitation to staff and their immediate families that need a safer haven in a hurricane is commendable, and I encourage it. 
The Hotel may or may not have sufficient guest lodges to house those from other Hotels. Therefore:

a) The banquet rooms could be utflized as dormitories for the overflow if the windows were shuttered.

b) Cots from the housekeeping department would be much more comfortable for the guests than the floor of a school hallway, and the food would be better prepared.

c) Courtesy transportation should be provided.

d) Off duty staff electing to remain at the Hotel because their houses are not too safe, should be utilized as volunteers to assist in making the dormitory residents more comfortable.

If management would decide in favor of evacuating, I would recommend:

a) Providing snacks and soft beverages (coffee, tea, soda) without charge around
the clock.

b) closing the bar early in the evening, possibly at 10:00 p.m. and with no free

c) Simple easy to prepare meals, served buffet style, at stated times.

The Greater Miami Chapter of the American Red Cross is willing and able to advise you further on developing a Hurricane Disaster Plan and providing training that may
be needed. 
APPENDIX J

EVACUATION NOTICE BY THE GOVERNOR 


\section{APPENDIX J}

EVACUATION NOTICE BY THE GOVERNOR

1. Inform all guests of the Governor's Evacuation order

a) Notice to be printed as follows:

"The: Governor of the State of Florida has issued an Evacuation Order which includes the location of this Hotel. This is mandatory and you must contact the Hotel's Hurricane Information Center for a list of approved shelters"

2. Utilize Taxi Cabs and Public Busses to accomplish the evacuation

3. Maintain a list of guests and employees who remain and why they would not evacuate

4. Check legal - Security remains - Security employees should be asked to volunteer
a) designate safety rooms and areas in Hotel
b) reinforce and supply those rooms

5. Security assignments to check and insure all have left the Hotel adequate supply of emergency masters - Ball Room 
SELECTED BIBLIOGRAPHY

A. Books, magazines, and newspapers

Bezold, Clement and Robert L. Olson. "The Future of Florida." Futurist, Oct. 1983, pp. 12-19.

Briggs, Peter. Rampage. New York: David McKay Company, Inc., $1973, \mathrm{p} \cdot \frac{117-123}{11}$

Burstein, Harvey. Hotel Security Management. New York, NY: Praeger Publishers, 1975 .

Buzby II, Walter J. and David Paine. Hotel and Motel Security Management. Los Angeles, California: Security World Publishing Co., Inc., 1976.

Donovan, Sharon. "Hurricane Alicia Checks In." Hotel and Motel Management, Oct. 1983, p. 3 .

Dunn, Gordon E. and Banner I. Miller. Atlantic Hurricanes. Louisiana: Louisiana State University Press, 1964.

Funk, Ben. "Hurricane!," National Geographic, Sept. 1980, p p. 346-380.

"Hurricane Preparedness." The Miami Herald, 19 July 1984, Section $\mathrm{HA}$.

"Hurricane Warning." People, 29 Aug. 1983, pp. 87-88.

Jackson, Donna. "Risk Management: What You Don't Know Can Hurt You." Foodservice Marketing, Sept. 1982, pp. 54-55.

Leedy, Paul D. Practical Research: Planning and Design. New York: MacMillan Publishing Co., Inc., 1980, p. 75.

Pardue, Leonard G. September, Remember.... Weatherwatch. Miami, F1orida, $198 \overline{2}$.

Pride, William M. and 0.C. Ferre11. Marketing, Basic Concepts and Decisions. Boston: Houghton Mifflin Company, 1980, p. 82 .

Reardon, L.F. The Florida Hurricane and Disaster. Miami: Publishing Company, 1926 .

"Storm Warnings." Wall Street Journal, 14 Oct.1983, p. 121. 
"The 1926 Hurricane." The Miami Herald, 7 June 1964, Section $\mathrm{H}, \mathrm{p} . \mathrm{l}$.

Townsend, R. Marvin. "Hurricanes: Tracking Many But Knowing Few." Public Management, Jan/Feb. 1981..

"When Hurricanes Hit, 'Complacency' Can Kill You." U.S. News and World Report, 18 Aug. 1980, p. 56 .

White, Gilbert F. and Eugene Haas. Assessment of Research on Natura 1 Hazards. Cambridge, Massachusetts: The MIT Press, 1975 .

\section{B. Bulletins and Unpublished Papers}

Emergency Bil1, 1980 .

Emergency. Measures. Federal Emergency Management Agency, 1984.

Hurricane. Miami: Metropolitan Dade County Office of Emergency Management, 1984 .

Hurricane Procedure Plan, Section I. Miami: Metropolitan Dade County Office of Emergency Management, 1984 .

Hurricanes, Florida and You. National Oceanic and Atmospheric Administration, 1984 .

Hurricane Survival. National Oceanic and Atmospheric Administration and the National Weather Service, 1984.

Mc Mullen, R. Hurricane Specialist, Metropolitan Dade County Office of Emergency Management, Miami, Florida. Interview, June 15,1984 .

Metro Dade Department of Tourism. Dade County Tourism Facts. Miami, 1984.

Survival in a Hurricane. Miami: National Hurricane Center, 1984. 